\title{
LEGAL BUT UNETHICAL: INTERROGATION AND MilitaRy Health Professionals
}

\author{
Eric Merriam ${ }^{1}$
}

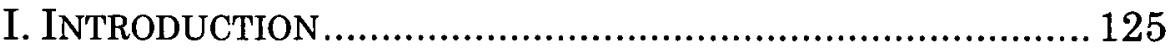

II. LEGAL AND PROFESSIONAL ETHICAL STANDARDS ........... 133

A. International Law.......................................... 133

B. United States Domestic Law.............................. 135

C. International Ethical Standards............................ 138

D. Domestic Ethical Standards.................................. 139

1. Professional Associations.................................. 140

2. State Licensing Bodies...................................... 142

III. APPLICATION OF LAW AND ETHICAL STANDARDS TO

Health PRofessionals' ACTIVITIES ........................... 146

A. General Involvement in Interrogation Planning and Training.

1. Examples: Headquarters-Level General Interrogation Plans and Methods Development.

2. Examples: Guantanamo Interrogation Plan Development................................................. 150

3. Examples: General Interrogation Training ........... 157

4. Application of Law and Ethical Standards to General Interrogation Involvement................................. 159

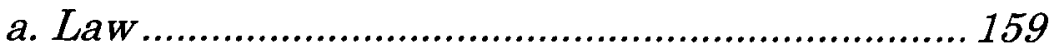

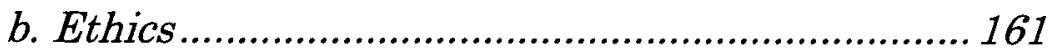

B. Direct Involvement in Specific Interrogation........... 163

1. Examples: Specific Interrogation Planning -

Interrogation of Mohammed Al-Qahtani ............... 164

a. Law ......................................................... 166

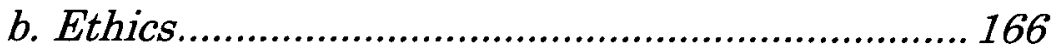

2. Examples: Intra-Interrogation Consultation......... 167

a. Law ............................................................. 173

b. Ethics......................................................... 175

1. Examples: Health Examinations and Interrogation

Monitoring.................................................... 176

1 Lieutenant Colonel, United States Air Force Judge Advocate General's Corps; Assistant Professor of Law, United States Air Force Academy. The views expressed are the author's alone and do not reflect the views of the United States Air Force or Department of Defense. 


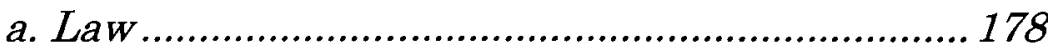

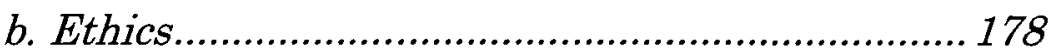

C. General Medical Care .......................................... 180

1. Examples: Failure to Identify or Report Evidence of Interrogation-Related Abuse ................................ 181

a. Law ................................................................. 184

b. Ethics.............................................................. 186

2. Examples: Concealing Interrogation-Related Injuries ......................................................... 186

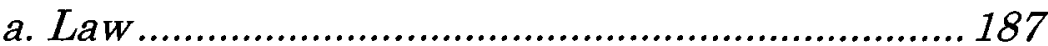

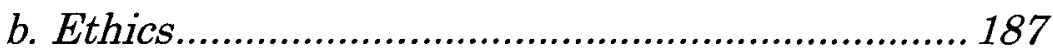

3. Examples: Withholding Care To Obtain

Cooperation ........................................................ 188

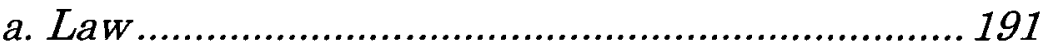

b. Ethics......................................................... 191

4. Examples: Providing Care for the Purpose of Furthering Interrogation................................... 192

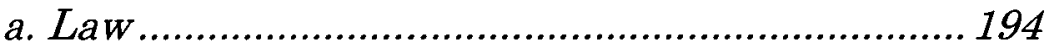

b. Ethics.............................................................. 195

5. Examples: Forced Feeding................................. 195

a. Law ............................................................ 197

6. Examples: Sharing Medical Information with Interrogation Teams .......................................... 199

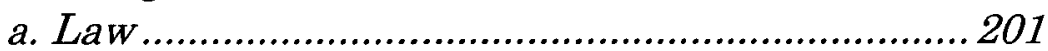

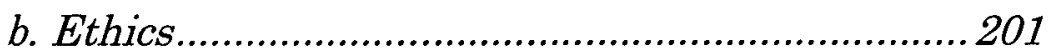

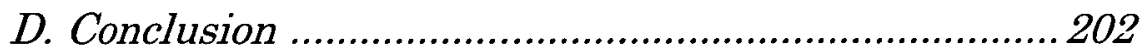

IV. CONCLUSION: THE IMPACT OF THE LAW-ETHICS DIVIDE

A. The Law-Ethics Gap Leaves MHPs Unempowered to

Protect Detainees.

204

1. Military Medical Community is Subordinate to Operational Actors............................................ 206

2. Professional Dual Loyalty...................................209

B. The Law-Ethics Gap Cedes Too Much Power to Professional Health Associations........................... 212

C. The Law-Ethics Gap May Exclude Health Professionals from Interrogation Process ...................................214

D. The Law-Ethics Gap Divide Harms MHPs ..............216

1. Professional Risks ............................................217

a. Health Professional Risks ................................217 
b. Military Professional Risks

1. Personal Risks .................................................219

a. Criminal Liability ............................................219

b. Civil/Tort Liability?...........................................221

E. Conclusion ............................................................221

\section{INTRODUCTION}

United States military health professionals ("MHPs"), ${ }^{2}$ including medical doctors and psychologists who have

2 Unless otherwise specified, the term HP refers to military medical and psychology providers. Of particular concern in this article are military physicians, including psychiatrists, and clinical psychologists, in part because their activities have been the greatest subject of debate, and because their professional organizations have been most vocal in articulating ethical standards in this area. A Department of Defense ("DoD") regulation addressing HPs' participation in interrogation-related activities defines "health professional" more broadly:

an individual who has received special training or education in a health-related field and who performs services in or for the Department of Defense in that field. A health-related field may include administration, direct provision of patient care, or ancillary or other support services. Health care personnel include, but are not limited to, individuals licensed, certified, or registered by a government agency or professional organization to provide specific health services.

U.S. DEP'T OF DEF., No. 2310.08E, DEPARTMENT OF DEFENSE INSTRUCTION: MEDICAL PROGRAM SUPPORT FOR DETAINEE OPERATIONS $\S$ 3.3 (June 6, 2006), [hereinafter DoDI 2310.08E], available at http://www.dtic.mil/whs/directives/corres/pdf/231008p.pdf. $\quad$ Other "health personnel," such as physician assistants, mental health technicians, nurses, and medics, are specifically identified where discussed. Though the interrogation-related actions of non-military medical providers, especially those of the Central Intelligence Agency's Office of Medical Services, are germane to questions regarding interrogation-related activities of medical personnel, this article focuses on military medical providers. Because of the greater complexity of military actions vis-à-vis the law of war, the unique position of military providers who may not refuse lawful orders, unlike civilian medical 
served at military detention facilities in Afghanistan, Guantanamo Bay, Cuba (Guantanamo), and Iraq, have been labeled "torturers" or war criminals for their interrogationrelated activities. ${ }^{3}$ Detractors have likened health professionals ("HPs") related to the interrogations at Guantanamo to Nazi war criminals:

The [military and CIA] health personnel who participated fulfilled the same role as the Nazi doctors by their decisions based on medicine, physiology, or psychology recommending or deciding on additional applications of interrogation regimens or combinations that

providers who can object to participation in objectionable activities by refusing or quitting, and the relatively greater amount of publicly available information regarding their activities, especially compared with non-MHPs at other, non-military-run, detention facilities.

3 See, e.g., Peter Slevin \& Joe Stephens, Detainees' Medical Files Shared; Guantanamo Interrogators' Access Criticized, WASH. PosT, June 10, 2004, at A1 ("Steven H. Miles, a professor of bioethics at the University of Minnesota, said that using [health] information in interrogations of detainees would be a 'clear-cut violation' of the Geneva Conventions."); Nat Hentoff, War Crimes by Doctors and Psychologists, ORANGEBURG TIMES AND DEMOCRAT (Oct. 1, 2009) http://thetandd.com/news/opinion/war-crimes-by-doctors-and-

psychologists/article_de63ff $47-7106-56 \mathrm{~cd}-\mathrm{be} 14-83397 \mathrm{~d} 832 \mathrm{~b} 7 \mathrm{e} . \mathrm{html}$ (last visited Nov. 26, 2013) (wondering whether professional associations will call for investigation of "health professionals' actual participation in war crimes under the Convention Against Torture and Other Cruel, Inhuman or Degrading Treatment or Punishment-as well as the Geneva Conventions and the U.S. Torture Act"); STEven H. MiLeS, OATH BETRAYED: AMERICA's TORTURE DOCTORS ix'x, 167 (2009) (asking "Where were the doctors at Abu Ghraib?" and asserting that "[t]orturers need medical accomplices"); David Brennan, Torture of Guantánamo Detainees with the Complicity of Medical Health Personnel: The Case for Accountability and Providing a Forum for Redress for These International Wrongs, 45 U.S.F. L. REV. 1005, 1006 (2011) [hereinafter Brennan, Torture of Detainees] ("Direct participation by medical health personnel in these activities constituted gross violations of international and domestic law, as well as their specific ethical and professional obligations."). 
interrogators could or should use, including the point at which interrogation had to stop. ${ }^{4}$

Even HPs who merely provided health care for detainees ${ }^{5}$ have not escaped condemnation, with critics charging "even those health professionals who sought to restrict themselves to clinical roles and steered clear of interrogation support became part of the machinery of torture" and "became enablers of torture by providing medical care in an environment where torture was taking place."6

Commentators suggest, quite correctly, that by virtue of their professions and proximity, HPs bear, or should bear, heightened responsibility to protect against interrogationrelated abuses. 7 However, critics have suggested,

4 Brennan, Torture of Detainees, supra note 3, at 1033. The comparison to Nazi doctors will be examined below.

5 Understanding that terms to describe individuals who are held against their will in the context of conflict-such as "prisoner," "captive," "retained personnel," and the like-have significance in the context of international law, the term "detainee" will be used to refer generally to all types of individuals detained for an extended period of time (not temporary battlefield detentions) by the United States in relation to its post-9/11wars in Iraq, Afghanistan, and against al Qaeda and affiliated terrorist networks.

6 Farnoosh Hashemian et al., Broken Laws, Broken Lives: Medical Evidence of Torture by US Personnel and its Impact, PHYSICIANS FOR HUMAN RIGHTS 85-86 (June 2008), available at https://s3.amazonaws.com/PHR_Reports/BrokenLaws_14.pdf (emphases added). The tenuous factual nature of this assertion, not to mention the legally unsupportable claim that by providing medical care to detainees HPs were somehow responsible for the interrogation abuses, is demonstrated by Physicians for Human Rights' ("PHR") own acknowledgment: "PHR has no information about whether physicians or other health personnel reported torture to authorities, but they surely did not intervene to stop torture when they were in its midst or were examining those subjected to it." Id.

7 See, e.g., MILES, supra note 3; Leonard S. Rubenstein, Complicity and the Illusion of Beneficence, in FORCED FEEDINGS, AND THE Role of Health Professionals (Ryan Goodman \& Mindy Jane Roseman eds. 2009); Stephanie Erin Brewer \& Jean Maria Arrigo, Places That Medical Ethics Can't Find: Preliminary Observations on Why Health Professionals Fail to Stop Torture in Overseas Counterterrorism Operations, in FORCED FEEDINGS, AND THE ROLE OF Health Professionals 1 (Ryan Goodman \& Mindy Jane Roseman eds. 
sometimes by inference and sometimes explicitly, that that heightened responsibility is imposed on HPs by both legal and professional ethical standards and some discussions have failed clearly to distinguish between legal and ethical standards, sometimes conflating the two. ${ }^{8}$ For example, the International Committee for the Red Cross ("ICRC") mixed applicable legal and ethical standards when it reported "the interrogation process is contrary to international law [to the extent that] participation of health personnel in such a process is contrary to international standards of medical ethics."9

2009) ("TT]he health community struggles to understand how medical professionals have stood by during episodes of severe detainees abuse in U.S.-controlled detention centers. ..."). Some critics may be arguing, justifiably, that, based on theories of accessory, accomplice, or conspiratorial liability, the circle of liable persons is larger than the people in the room during the interrogations, reminding us to add HPs to a list that includes commanders, civilian leaders, and attorneys who authorized illegal activities. The purpose of this article is to demonstrate such secondary liability is the only real constraint on HPs that law imposes-none directly addresses HPs' activities.

8 See, e.g., Brennan, Torture of Detainees, supra note 3, at 1006 ("Direct participation by medical health personnel in these activities constituted gross violations of international and domestic law, as well as their specific ethical and professional obligations.") and at 1041-43 (arguing OLC's memoranda regarding legality of interrogation methods should have addressed "medical health personnel's potential culpability" under "recognized codified principles" such as the 1947 Nuremberg Code; 1948 Declaration of Geneva; Universal Declaration of Human Rights; and World Medical Association's ("WMA") International Code of Medical Ethics, as incorporated in the WMA's 1964 Declaration of Helsinki, WMA's 1975 Declaration of Tokyo, and WMA's 2005 Medical Ethics Manual, without distinguishing or explaining these instruments' varying legal effects); MILES, supra note 3 , at xii ("The international laws and medical ethics codes pertaining to torture are not finicky rules. ... [they] are breathing expressions of global moral aspiration.") and at 5 (quoting both the Convention Against Torture and WMA's "Guidelines for Medical Doctors Concerning Torture and Other Cruel, Inhuman or Degrading Treatment or Punishment in Relation to Detention and Imprisonment" as support for argument that torture is a "crime against humanity").

9 ICRC Report on the Treatment of Fourteen "High Value Detainees" in CIA Custody, INT'L COMM. OF THE RED CROSS 23 (2007) [hereinafter ICRC Report of 2007], available at http://www.nybooks.com/media/doc/2010/04/22/icrc-report.pdf. 
Much of the post-9/11 debate and scholarship regarding MHPs' detainee-related activities have occurred in the professional medical ethics arenas, with comparatively limited focused analysis on international and domestic legal regimes specifically affecting MHPs' activities. ${ }^{10}$

10 See, e.g., MILES, supra note 3; Jonathan H. Marks, Doctors as Pawns? Law and Medical Ethics at Guantánamo Bay, 37 SETON HALL L. REV. 711 (2007) [hereinafter Marks, Doctors as Pawns]; Jonathan H. Marks, Looking Back, Thinking Ahead: The Complicity of Health Professionals in Detainee Abuse, in INTERROGATIONS, FORCED FeEdings, AND THE Role of Health PRofessionals 30 (Ryan Goodman \& Mindy Jane Roseman eds. 2009) [hereinafter Marks, Looking Back]; Rubenstein, supra note 7. As will be demonstrated in this article, this focus on ethics is perhaps necessary; specific law is sparse.

The relative absence of academic assessment should perhaps not be surprising, as it follows apparent practitioner oversight of the many laws directly affecting medical personnel; the several iterations of legal memoranda approving "enhanced interrogation" failed to address legal considerations governing medical personnel activities in hostilities and interrogation. See, e.g., Memo from Assistant Attorney General Jay Bybee to White House Counsel Alberto Gonzales, Standards of Conduct for Interrogation under 18 U.S.C. $\$ \S 2340-2340 \mathrm{~A}$ (Aug. 1, 2002) [hereinafter Bybee Memo to Gonzales] (providing no analysis of law and ethical standards governing participation by HPs). In fact, the only mention of medical personnel in these memoranda was to require their involvement, thus pulling medical personnel into potentially illegal activities without discussing whether there were legal issues specific to them. See, e.g., Memorandum from Donald Rumsfeld on CounterResistance Techniques in the War on Terrorism to the Commander, U.S. Southern Command (Apr. 16, 2003), [hereinafter Rumsfeld Approval Memorandum of April 2003], available at http://www.torturingdemocracy.org/documents/20030416.pdf;

Memorandum from Steven G. Bradbury, Principal Deputy Assistant Attorney General, Office of Legal Counsel, U.S. Dep't of Justice, to John A. Rizzo, Senior Deputy Gen. Counsel, Central Intelligence Agency, Re: Application of 18 U.S.C. $\S \S 2340-2340$ A to Certain Techniques that May $\mathrm{Be}$ Used in the Interrogation of a High Value al Qaeda Detainee 6-8 (May 10, 2005) [hereinafter Bradbury Memo of May 2005]. Bradbury documents the CIA's Office of Medical Services involvement in evaluating detainees before any enhanced technique is authorized in order to ensure that the detainee is not likely to suffer any severe physical or mental pain or suffering as a result of interrogation. Id.

The field is not completely devoid of valuable legal analysis and contribution. While the author disagrees with some of their arguments and conclusions, the thoughtful and detailed scholarship of Professor Jonathan H. Marks and sometimes co-author Dr. Gregg Bloche in this 
The purpose of this article is to demonstrate that while professional ethical standards provided-or evolved to provide-increased responsibility on MHPs for their interrogation-related activities, international and domestic law did not. To be clear, this article does not argue that no law applied to or limited MHPs' interrogation related activities. Indeed, there is significant international and domestic law regarding interrogation of detainees. However, the law generally does not treat HPs differently than non-HPs, either by identifying them as a separate class of actors or by substantively and specifically prescribing or proscribing HPs' interrogation-related activities. Thus, professional ethical standards prohibit MHPs from engaging in a wide range of interrogationrelated activities that international and domestic law does not, and the law generally imposes no greater burden or responsibility for protecting human rights on MHPs than on non-HP service members. While this gap between law and ethics is occasionally due to an actual conflict between legal and ethical standards, more often it is because law is silent regarding participation by HPs in the type of interrogationrelated activity at issue. Further, in limited areas where law does prescribe health-specific interrogation-related activities, such as medical experimentation on detainees, the facts alleged by critics do not constitute violations of the law by MHPs.

With the exception of a brief assessment of possible secondary liability for HPs, the analysis and conclusions do not rely on whether "enhanced interrogation techniques" constituted torture or were illegal and this paper does not attempt to resolve the dispute. ${ }^{11}$ Further, this paper makes

area is noteworthy. See, e.g., M.G. Bloche \& J.H. Marks, When Doctors Go To War, 352 NEW ENG. J. MED. 3, 4 (2004) [hereinafter Bloche \& Marks, Doctors Go To War\}; Jonathan H. Marks, Doctors as Pawns, supra note 10; and Marks, Looking Back, supra note 10.

11 In fact, for the purpose of this article, one may agree with the conclusions of many commentators-and as was recently learned, the opinion of a senior advisor in the Bush Administration's State Department-that several of the so-called "enhanced interrogation techniques" employed by military personnel, including waterboarding, stress positions, cramped confinement, sleep deprivation, and nudity, 
no attempt to resolve whether various international laws were applicable to all types of detainees in all military detention locations. ${ }^{12}$ Not all laws discussed in this paper applied to all detainees in all locations, but so long as a law arguably applied to some military detainees in some locations, it is included. Also, the paper does not attempt to determine conclusively whether MHPs actually violated the law, a point rendered somewhat moot domestically by the criminal and civil absolution provided in the Military Commissions Act of 2006.13 Rather, this paper addresses the broader question of whether law, as opposed to ethical standards, actually prohibits the types of interrogationrelated conduct in which MHPs engaged that give rise to allegations of malfeasance. This paper provides some specific instances of the type of misconduct critics allege was unlawful or improper, but only to illustrate the activity, rather than to serve as a platform for applying law and ethics to a specific set of facts. Finally, though there are many aspects of HPs' involvement in detainee operations that are addressed by international and domestic law, including general sanitation, food quality, and security concerns at detention facilities, this paper addresses only MHPs' interrogation-related activities.

MHPs are associated with detainee interrogation in a variety of ways, with activities covering a spectrum from direct involvement in specific interrogation sessions to unrelated medical care for detainees who also happen to be subject to interrogation. Activities along this spectrum

constitute torture or cruel, inhuman, or degrading treatment under international law, United States domestic law, or both. See Draft Memorandum from Philip D. Zelikow, The McCain Amendment and U.S. Obligations under Article 16 of the Convention Against Torture 6 (Feb. 15, 2006), available at http://www2.gwu.edu/ nsarchiv/news/

20120403/. That memorandum addressed torture after the so-called "McCain Amendment." Id.

12 For example, though it will be briefly referenced below, the paper does not resolve whether detainees in Guantanamo were entitled to protections of Geneva Conventions other than Common Article 3, or whether some detainees in Iraq were entitled to them while others were not.

13 Military Commissions Act of 2006, Pub. L. No. 109-366, 120 Stat. 2600 (2006). 
have been criticized as violating legal and professional ethical standards. ${ }^{14}$ This article groups these activities in three ways: 1) general interrogation involvement, including planning and methods development and training; 2) specific interrogation involvement, including specific interrogation planning, specific intra-interrogation consulting, monitoring during interrogation sessions, pre- and post-interrogation assessments, and alleged interrogation-related medical experiments; and 3) general medical and psychological care for interrogated detainees that is generally unrelated to interrogation but that nevertheless gives rise to allegations of interrogation-related misconduct, including allegations of failure to report and concealing abuse, withholding care to obtain information, providing care for the purpose of furthering interrogation, forced feeding, and sharing medical information with interrogators.

Just as MHPs' interrogation-related activities occupy a spectrum, so too do the variety of instruments that could proscribe or prescribe those activities exist along a spectrum ranging from legal (including treaty, customary international law, and domestic statutes and regulations) to ethical standards pronounced by various professional associations. These types of instruments have varying effects, with treaties imposing contractual obligations on states, other international and domestic law imposing criminal or civil liability on individuals, and ethical standards providing powerful personal and professional incentives for compliance, including possible impact on licensing and professional censure, or perhaps constituting evidence of professional misconduct giving rise to civil liability.

14 See, e.g., Brennan, Torture of Detainees, supra note 3, at 1006 ("Direct participation by medical health personnel in these activities constituted gross violations of international and domestic law, as well as their specific ethical and professional obligations."); Hashemian et al., supra note 6 , at 7 (asserting that "medical personnel played a role in facilitating torture and ill-treatment in all three theatres of operations through the monitoring of abuse during interrogations, providing medical information to interrogators, denying medical care, and failing to take action to stop and/or document detainee abuse."); MILES, supra note 3; Hentoff, supra note 3; Marks, Doctors as Pawns, supra note 10. 
Section II is a brief summary of the international and domestic law and professional ethical standards affecting MHPs' interrogation-related activities. In Section III, the law and ethical standards are applied to the types of interrogation-related activities involving MHPs about which critics have complained, illustrating the significant divide between legal prohibitions and professional ethical standards. Exploring these various instruments will demonstrate the law does little to proscribe HPs' interrogation-related activities or establish professionals as guardians of human rights in the interrogation, while professional ethics clearly do. The paper concludes with a brief discussion of why the lack of legal prohibitions in the face of significant and specific ethical standards is problematic.

\section{LEGAL AND PROFEsSional ETHICAL STANDARDS}

\section{A. International Law}

The primary sources of international law that could potentially bear on medical providers' interrogation-related activities during armed conflict are the following: the Geneva Conventions, including Article 75 of Optional Protocol I; 15 the Convention Against Torture and Other Cruel, Inhuman or Degrading Treatment or Punishment

15 Geneva Convention Relative to the Amelioration of the Condition of the Wounded and Sick in Armed Forces in the Field, Aug. 12, 1949, 6 U.S.T. 3114, 75 U.N.T.S. 31 [hereinafter Geneva I]; Geneva Convention Relative to the Amelioration of the Condition of Wounded, Sick and Shipwrecked Members of Armed Forces at Sea, Aug. 12, 1949, 6 U.S.T. 3217, 75 U.N.T.S. 85 [hereinafter Geneva II]; Geneva Convention Relative to the Treatment of Prisoners of War, Aug. 12, 1949, 6 U.S.T. 3316, 75 U.N.T.S. 135 [hereinafter Geneva III]; Geneva Convention Relative to the Protection of Civilian Persons in Time of War, Aug. 12, 1949, 6 U.S.T. 3516, 75 U.N.T.S. 287 [hereinafter Geneva IV]; and Protocol Additional to the Geneva Conventions of 12 August 1949, and Relating to the Protection of Victims of International Armed Conflicts (Protocol I), June 8, 1977, 1125 U.N.T.S. 3 [hereinafter Protocol I]. 
("Convention Against Torture" or "CAT"); 16 and the Nuremberg Code. ${ }^{17}$ As will be demonstrated below, while

16 G.A. Res. 39/46, U.N. Doc. A/RES/39/46 (Dec. 10, 1984) [hereinafter Convention Against Torture or CAT].

17 The Nuremberg Code (1947), available at http://www.cirp.org/ library/ethics/nuremberg/ (last updated June 9, 2002) [hereinafter Nuremberg Code]. Often cited by commentators arguing that United States MHPs violated the law in GWOT interrogations, the Nuremberg Code is not a "code" as lawyers understand the term, but is actually dicta in the judgment of the court in the post-World War II trial of Nazi doctors. See, e.g., Brennan, Torture of Detainees, supra note 3, at 1040 (arguing that "viewed through the Nuremberg Code," United States HPs violated the law). There is significant debate regarding the legal effect of the Nuremberg Code. See Sharon Perley et al., The Nuremberg Code: An International Overview, in THE NAZI DOCTORS AND THE NUREMBERG CODE: HuMAN RightS IN HUMAN EXPERIMENTATION 149 (George J. Annas \& Michael A. Grodin ed., Oxford Univ. Press 1992); George J. ANNAS et al., INFORMED CONSENT TO HUMAN EXPERIMENTATION: THE SUBJECT'S DILEMMA 122 (1977).

Most United States courts addressing the status of the Nuremberg Code and Declaration of Helsinki have concluded they are not binding and create no cause of action. See, e.g., Ammend v. BioPort, Inc., 322 F. Supp. 2d 848, 872 (W.D. Mich. 2004) (finding no Supreme Court precedent establishing the Nuremberg Code or Declaration of Helsinki as a constitutional right and holding that there is no private right of action for an alleged violation of international law for the protection of human research subjects under the Declaration of Helsinki and the Nuremberg Code); White v. Paulsen, 997 F. Supp. 1380, 1383 (E.D. Wash. 1998); and Hoover v. W. Va. Dep't of Health and Human Res., 984 F. Supp. 978 (S.D. W. Va. 1997), aff'd 129 F.3d 1259 (4th Cir. 1997). However, the norms articulated in the Nuremberg Code (and later, the Declaration of Helsinki, discussed below) clearly constitute customary international law. One United States court found the Nuremberg trials' "authorizing documents" and judgments established legal principles that became the "bedrock norms of international law." See, e.g., Abdullahi v. Pfizer, Inc., 562 F.3d 163, 177-79 (2d Cir. 2009) (noting that at least eighty-three other countries had incorporated the Declaration of Helsinki into their laws regulating informed consent of human subjects and concluding "the sources on which our government relied in outlawing non-consensual human medical experimentation were the Nuremberg Code and the Declaration of Helsinki, which suggests the government conceived of these sources' articulation of the norm as a legal obligation.").

Several additional regional and international instruments that address the alleged underlying misconduct at issue here-especially torture-will not be presented because they are inapplicable to the regions at issue or because their prohibitions parrot, in substance and 
these laws address treatment of detainees and interrogation, they do not specifically prescribe or proscribe health professionals' behavior as it relates to interrogation and, therefore, fail to sufficiently regulate such conduct. ${ }^{18}$

\section{B. United States Domestic Law}

A variety of United States domestic laws potentially apply to MHPs' interrogation-related activities, including

form, the instruments that are discussed here. See, e.g., American Convention on Human Rights, Nov. 22, 1969, art. 5, 1144 U.N.T.S. 123 ("No one shall be subjected to torture or to cruel, inhuman or degrading treatment or punishment."); Inter-American Convention to Prevent and Punish Torture, O.A.S.T.S. No. 67 (entered into force Feb. 28, 1987), reprinted in Basic Documents Pertaining to Human Rights in the InterAmerican System, OEA/Ser.L/V/II.82 doc. 6 rev. 1 at 83 (1992); European Convention for the Protection of Human Rights and Fundamental Freedoms, Nov. 4, 1950, art. 3, 213 U.N.T.S. 221, as amended by Protocols Nos. 3, 5, 8, and 11 (entered into force Sept. 21, 1970, Dec. 20, 1971, Jan. 1, 1990, and Nov. 1, 1998) ("No one shall be subjected to torture or to inhumane or degrading treatment or punishment."); European Convention for the Prevention of Torture and Inhuman or Degrading Treatment or Punishment, E.T.S. 126 (entered into force Feb. 1, 1989); African [Banjul] Charter on Human and Peoples' Rights, adopted June 27, 1981, art. 5, OAU Doc. CAB/LEG/67/3 rev. 5, 21 I.L.M. 58 (1982) (entered into force Oct. 21, 1986) ("All forms of exploitation and degradation of man particularly slavery, slave trade, torture, cruel, inhuman or degrading punishment and treatment shall be prohibited."); and Revised Arab Charter on Human Rights, May 22, 2004, art. 8.1 (entered into force March 15, 2008), reprinted in 12 Int'l H.R. Rep. 893 (2005) ("No one shall be subjected to physical or psychological torture or to cruel, degrading, humiliating or inhuman treatment.").

18 Because this article applies available law to the types of military professionals' interrogation-related activities alleged to be improper, rather than analyzing specific cases, if a particular law was relevant to any interrogations of military detainees in the Global War on Terror ("GWOT"), it is considered presented here. 
federal statutes and regulations. ${ }^{19}$ Some of these measures are the United States' implementation of treaty obligations, while others are independently undertaken by the United States. Relevant domestic laws include the following: the so-called Anti-Torture Statute;20 War Crimes Act ("WCA");21 Detainee Treatment Act of 2005 ("DTA"); 22 Military Commissions Act of 2006 ("MCA");23 the Uniform Code of Military Justice ("UCMJ"); 24 and various Department of Defense ("DoD") regulations. ${ }^{25}$

19 Various states including New York, California, and Massachusetts have also considered torture-related activities of HPs. See Tara A. Lewis, Did CIA Doctors Experiment on Terror Suspects?, NEWSWEEK (Jun. 24, 2010, 5:00 AM), http://www.thedailybeast.com/ newsweek/2010/06/24/did-cia-doctors-experiment-on-torturesuspects.html. Though clearly relevant to individual HPs, a state survey is beyond the scope of this article, which is intended to apply all United States MHPs.

20 18 U.S.C. $\S \S 2340-2340$ A (2013).

$21 \quad 18$ U.S.C. $\$ 2441$ (2013).

22 The Detainee Treatment Act is actually identically presented in two different pieces of enacted legislation: the Department of Defense, Emergency Supplemental Appropriations to Address Hurricanes in the Gulf of Mexico, and Pandemic Influenza Act, Pub. L. 109-148 (2005) and the National Defense Authorization Act for Fiscal Year 2006, Pub. L. No. 109-63, 3136, 3475-76 (2006).

23 Military Commissions Act of 2006, Pub. L. No. 109-366, 120 Stat. 2600 (2006).

2410 U.S.C. $\S \S 801-946$. The Uniform Code of Military Justice has no specific provisions criminalizing specific behavior by MHPs, but has several provisions that could be used to prosecute MHPs-as well as any service member-for interrogation-related offenses, including Articles 92 (failure to obey lawful orders and regulations), 93 (maltreatment of subordinates), 128 (assault offenses), and 134 ("disorders and neglects" to the prejudice of good order and discipline in the armed forces; conduct of a nature to bring discredit upon the armed forces).

25 Regulations specifically addressing MHPs' interrogation-related activities include DoDI 2310.08E, supra note 2; Enemy Prisoners of War, Retained Personnel, Civilian Internees and Other Detainees, AR 190-8 (Oct. 1 1997); and the two Army "Field Manuals": U.S. DEP'T OF THE ARMY, FIELD MANUAL 34-52: INTELLIGENCE INTERROGATION (1997) [hereinafter 1997 Field Manual] was replaced by the U.S. DEP'T OF THE ARMY, FIELD MANUAL 2-22.3: HUMAN INTELligENCE COLlECTOR OPERATIONS (2006) [hereinafter 2006 FIELD MANUAL]. 
Of direct relevance to this paper, DoDI $2310.08 \mathrm{E}$ was the DoD's late attempt to clarify HPs' roles in detainee treatment. This instruction addressed several important policy principles in the debate regarding HPs' involvement in detention-based interrogation activities. Regarding HPs' general duty to detainees, including matters related to interrogation, it states:

4.1.1. Health care personnel have a duty in all matters affecting the physical and mental health of detainees . . . to uphold the humane treatment of detainees and to ensure that no individual in the custody or under the physical control of the Department of Defense, regardless of nationality or physical location, shall be subject to cruel, inhuman, or degrading treatment or punishment, in accordance with and as defined in U.S. law.

\subsubsection{Health care personnel charged with the} medical care of detainees have a duty to protect detainees' physical and mental health

Additional regulations include DoD Directive ("DoDD") 6025.18-R, DoD Health Information Privacy Regulation (2003); DoDD 2310.1, DoD Program for Enemy Prisoners of War (EPOW) and Other Detainees (1994); DoDD 3115.09, DoD Intelligence Interrogations, Detainee Debriefings, and Tactical Questioning (2008); DoDD 5100.77, DoD Law of War Program, (1998); DoDD 3216.2, Protection of Human Subjects and Adherence to Ethical Standards in DoD-Supported Research (2002) [hereinafter DoDD 3216.2]; Health Affairs Policy 05-006, Medical Program Principles and Procedures for the Protection and Treatment of Detainees in the Custody of the Armed Forces of the United States (2005), withdrawn, DoDI 2310.08E, supra note 2, § 1(a) [hereinafter HA Policy 05-006]; Health Affairs Policy 05-019, Training for Health Care Providers in Detainee Operations (2005); J. CHIEFS OF STAFF, JP 3-63, JoInT DOCTRINE FOR DETAINEE OPERATIONS (2008); J. CHIEFs OF STAFF, JP 4-02, DOCTRINE FOR HEALTH SERVICE SUPPORT IN JOINT OPERATIONS (2006); DEP'T OF THE ARMY, DA G-2, INTERIM INTELLIGENCE INTERROGATION POLICY (2007); 2006 FIELD MANUAL; U.S. DEP'T OF THE ARMY, FIELD MANUAL 3-19.40: INTERNMENT/RESETTLEMENT OPERATIONS (2007). 
and provide appropriate treatment for disease.

4.1.4. Health care personnel, whether or not in a professional provider-patient treatment relationship, shall not apply their knowledge and skills in a manner that is not in accordance with applicable law. ...

4.1.5. Health care personnel shall not certify, or participate in the certification of, the fitness of detainees for any form of treatment or punishment that is not in accordance with applicable law, or participate in any way in the administration of any such treatment or punishment. ${ }^{26}$

\section{International Ethical Standards}

While few laws specifically relate to healthcare personnel and their interrogation-related activities, a number of professional ethical standards from international and domestic bodies directly relate to the interrogationrelated activities of MHPs. ${ }^{27}$ Ethical standards are not

26 DoDI 2310.08E, supra note $2, \S 4.1 .1-4.1 .5$. DoDI 2310.08E also contains the clearest articulation of the DoD's view that the appropriate way to address medical provider participation in interrogation was to bifurcate all activities into two categories. See id. $\S 4.3$ ("Health care personnel engaged in a professional provider-patient treatment relationship with detainees shall not participate in detainee-related activities for purposes other than health care.")

27 See, e.g., G.A. Res. 37/194, Annex, U.N. Doc. A/RES/37/194 (Dec. 18, 1982) [hereinafter U.N. Principles of Medical Ethics], available at http://www.wma.net/en/30publications/10policies/b3/index.html.pdf;

WORLD MED. ASS'N, WMA DECLARATION OF HELSINKI-ETHICAL PRINCIPLES FOR MEDICAL RESEARCH INVOLVING HUMAN SUBJECTS, available at http://www.wma.net/en/30publications/10policies/b3/ [hereinafter Declaration of Helsinki]; DECLARATION OF TOKYO (1975): GUIDELINES FOR PHYSICIANS CONCERNING TORTURE AND OTHER CRUEL, INHUMAN OR DEgRADING TREATMENT OR PUNISHMENT IN RELATION TO DETENTION AND IMPRISONMENT, WORLD MED. ASS'N (1975) [hereinafter DECLARATION OF TOKYO], a vailable at $\mathrm{http}$ ://www.cirp.org/library/ethics/ 
"law," but can influence HPs' personal and professional behavior in meaningful ways. Nevertheless, as argued in Section IV, where ethical standards are unsupported by law, they are insufficient to the task of establishing HPs as guardians of human rights in interrogation settings and the resulting divide between law and ethics has negative consequences.

\section{Domestic Ethical Standards}

Like international professional associations, domestic professional associations do not have the power to enforce their ethical standards. The most professional associations can do to discipline a member is to revoke membership in the association, and membership is not required to practice (much like membership in the American Bar Association is not required practice law). ${ }^{28}$ State licensing boards directly determine whether a physician, psychiatrist, or psychologist may practice, and thus they hold the only direct enforcement power when addressing professional ethics issues. However, domestic ethical standards are nevertheless influential and have the ability to persuade HPs to act in accordance with them. Some state licensing boards enforce domestic professional associations' ethical standards, rendering domestic standards perhaps more influential than international standards in terms of their ability to guide individual HPs' actions. Additionally,

tokyo; WORLD MED. ASS'N, Revised Declaration of Tokyo, available at http://www.un.org/documents/ga/res/37/a37r194.htm;

WMA

REgulations IN TIMEs OF ARMEd CONFLiCT AND OTHER Situations OF VIOLENCE, WORLD MED. ASS'N, para. 2 (2006) [hereinafter Regulations in Times of Armed Conflict], available at http://www.wma.net/ en/30publications/10policies/a20/ (last visited Dec. 23, 2013). In this article, the term "standards" applies to all "codes," regulations, and pronouncements of international and domestic bodies governing healthcare practice.

28 See Ty Alper, The Role Of State Medical Boards In Regulating Physician Participation In Executions, 95 J. MED. LICENSURE AND DISCIPLINE, no. 3,2009 , at 16,18 (also noting only $20 \%$ of doctors in the United States are members of the American Medical Association ("AMA")), available at http://papers.ssrn.com/sol3/papers.cfm? abstract_id=1544623. 
professional associations' standards are routinely cited by ethicists and HPs, which demonstrates their importance.

\section{Professional Associations}

Domestic ethical standards relevant to MHPs' interrogation-related activities issued by professional associations include the American Medical Association's ("AMA") ethical guidelines; 29 a position paper issued by the American Psychiatric Association ("2006 Position Statement"); 30 and various positions articulated by the American Psychological Association ("APA"), including its Report of the American Psychological Association Presidential Task Force on Psychological Ethics and National Security,"31 Resolution Against Torture and Cruel,

29 The AMA's guidelines generally conform to the WMA's Declaration of Helsinki and the Declaration of Tokyo. AMA Code of Medical Ethics, Opinion 2.067, Torture [hereinafter AMA Opinion 2.067] and AMA Code of Medical Ethics, Opinion 2.068, Physician Participation in Interrogation [hereinafter AMA Opinion 2.068], both available at http://www.ama-assn.org/ama/pub/physician-resources/ medical-ethics/code-medical-ethics.page?. The AMA's prohibition on physician participation in torture predates the GWOT, but the organization did not formally take a position on the role of physicians in interrogation until 2006, when it promulgated new ethical guidelines stating "[p]hysicians must neither conduct nor directly participate in, or monitor an interrogation, because a role as physician-interrogator undermines the physician's role as healer and thereby erodes trust in the individual physician-interrogator and in the medical profession."

30 Position Statement ON PSYchiatric PARTICIPATION IN INTERROGATION OF DETAINEES, AM. PSYCHIATRIC ASS'N(2006), available at http://www.psychiatry.org/File\%20Library/Advocacy $\% 20$ and $\%$ 20Newsroom/Position\%20Statements/ps2006_Interrogation.pdf [hereinafter 2006 Position Statement].

31 REPORT OF THE AMERICAN PSYCHOLOGICAL ASSOCIATION Presidential TASK Force on Psychological Ethics and National SECURITY, AM. PsYCHOLOGICAL Ass'N (2005), available at http://www.apa.org/pubs/info/reports/pens.pdf [hereinafter PENS Task Force Report]. The PENS Task Force has been widely criticized, in part because a significant number of its members were associated with military or national security apparatus. See, e.g., Tara McKelvey, First Do Some Harm, THE AMERICAN Prospect, Sept. 1, 2005, http://www.prospect.org/web/printfriendly-view.ww?id=10110; Brad Olson et al., The Ethics of Interrogation and the American Psychological 
Inhuman, and Degrading Treatment ("2006 APA Resolution Against Torture"), ${ }^{32}$ and the 2008 APA Resolution Against Torture. ${ }^{33}$

Association: A Critique of Policy and Process, 3 PHIL. ETHICS AND HUMAN. MED. (2008), available at http://www.peh-med.com/content/3/1/3 (a thorough critique of the process and substance of the PENS Task Force Report). One recommendation specifically allowed participation by psychologists in activities involving interrogations where "national security issues" were involved. Id. at 7 . Proscriptions against psychologists' participation in abusive interrogation were not defined by reference to international law, but rather tied to "applicable" United States rules and regulations as "developed and refined" since 9/11, thus tying psychologists' ethical obligations to the Administration's interpretation of the applicable law. Marks, Doctors as Pawns, supra note 10 , at 723 .

32 RESOLUTION AGAINST TORTURE AND CRUEL, INHUMAN, AND Degrading Treatment or Punishment, AM. Psychological Ass'N (2006), available at http://www.apa.org/about/policy/chapter3.aspx\#torture-punishment [hereinafter 2006 APA Resolution Against Torture], under which psychologists must not "knowingly engage in, tolerate, direct, support, advise, or offer training" in torture, cruel, inhuman, and degrading treatment. In describing the 2006 APA Resolution Against Torture, one commentator observed, "these regulations require psychologists to obey the laws that bind us all. Beyond that, psychologists have only their consciences as a guide." Marks, Doctors as Pawns, supra note 10, at 726-27.

33 AMENDMENT TO THE REAFFIRMATION OF THE AMERICAN Psychological Association Position AGAINST Torture AND OTHER Cruel, Inhuman, or Degrading TReatment or Punishment and ITS APPLICATION TO INDIVIDUALS DEFINED IN THE UNITED STATES CODE AS "ENEMY COMBATANTS", AM. PSYCHOLOGICAL ASS'N (2008) [hereinafter 2008 APA Resolution Against Torture], available at http://www.apa.org/news/press/statements/ethics-statement-torture.pdf. The 2008 APA Resolution Against Torture modified the 2006 APA Resolution Against Torture and clearly tied its prohibitions both to international law and to principles of professional ethics, declaring those sources required an absolute prohibition on the following techniques:

mock executions; water-boarding or any other form of simulated drowning or suffocation; sexual humiliation; rape; cultural or religious humiliation; exploitation of fears, phobias or psychopathology; induced hypothermia; the use of psychotropic drugs or mindaltering substances; hooding; forced nakedness; stress positions; the use of dogs to threaten or intimidate; physical assault including slapping or shaking; 


\section{State Licensing Bodies}

State licensing bodies, typically referred to as "boards," are the only organizations with authority to directly enforce professional standards of HPs. The professional associations' ethical policies identified above ostensibly enjoy their greatest enforcement power, although it is indirect, in states where licensing boards are permitted to take action against HPs for violations of the professional association's code, as referenced or assimilated by the licensing body. Though some state licensing boards incorporate professional association ethics into their rules, many do not. ${ }^{34}$ In practice, state licensing boards have been reluctant to discipline member HPs based on complaints

exposure to extreme heat or cold; threats of harm or death; isolation; sensory deprivation and overstimulation; sleep deprivation; or the threatened use of any of the above techniques to an individual or to members of an individual's family.

Id. at 2. The 2008 APA Resolution Against Torture specifically prohibited psychologists from "knowingly planning, designing, participating in or assisting in the use of all condemned techniques at any time...." Id.

34 For example, statutory or regulatory incorporation of the AMA Ethics Guidelines into the state licensing body's rules exists in only a minority of states: Alaska, Hawaii, Iowa, Kentucky, Maryland, Mississippi, Nebraska, New Hampshire, New Mexico, Ohio, Tennessee, and West Virginia. Alper, supra note 28, at 22. Of those, Hawaii, Kentucky, and Ohio expressly empower the state medical board to discipline physicians for conduct that violates the AMA's Code of Ethics. Ayham Bahnassi, Keeping Doctors Out Of The Interrogation Room: A New Ethical Obligation that Requires the Backing of the Law, 19 HEALTH MATRIX 447, 483 (2009). 
suggesting HPs' interrogation-related activities ostensibly violated the professional associations' ethical rules. ${ }^{35}$

Even state licensing bodies do not wield unfettered authority, a reality clearly demonstrated in the analogous area of lethal injection. The AMA and various state licensing boards have prohibited physician participation in lethal injection since 1980, but despite physician participation in hundreds of such executions, no physician has been disciplined, and courts have blocked state licensing boards that have attempted to do so. ${ }^{36}$

35 For example, a psychologist filed a complaint with the New York State Education Department's Office of Professional Discipline against the New York-licensed BSCT psychologist who helped create the BSCT Counter-Resistance Strategy Memorandum, discussed below, requesting approval for various enhanced interrogation techniques and who was present during at least some of the Qahtani interrogation. When Healers Harm: Hold Health Professionals Accountable for Torture, CENTER FOR CONST. RTS., http://whenhealersharm.org/john-leso (last visited Dec. 26, 2013). New York's Director of Investigations rejected the complaint via telephone claiming the office "lacked jurisdiction" over the matter. Id. A New York state trial judge subsequently refused to force the New York office of Professional Discipline to investigate the matter. John Eligion, Judge Won't Order Inquiry Over Psychologist's Role in Guantánamo, N.Y. TIMEs (Aug. 12, 2011), http://www.nytimes.com/2011/08/12/nyregion/judge-wont-order-inquiryover-psychologists-role-in-guantanamo.html. Additionally, at least four complaints have been filed against this psychologist with the Ethics Committee of the American Psychological Association. CENTER FOR CONST. RTS., supra. None has been acted upon. Similar complaints against other military psychologists in Louisiana, Ohio, and Texas have also not been acted upon. $I d$.

36 See, e.g., Order Granting Plaintiff's Request for Declaratory Relief \& Denying Defendant's Motion to Dismiss at 5, N.C. Dep't. of Corr. v. N.C. Med. Bd., No. 07-CVS-3574 (N.C. Super. Ct. Sept. 21, 2007), http://www.newsobserver.com/content/media/2007/9/21/

D0C092107.pdf (granting the North Carolina Department of Corrections' request for an injunction against the North Carolina Medical Board preventing it from "taking disciplinary action against physicians who have participated in or otherwise have been involved in judicial executions by lethal injection" because state law specifically authorizes lethal injection); Zitrin v. Ga. Composite State Bd. of Med. Examiners, 653 S.E.2d 758, 763 (Ga. Ct. App. 2007) (upholding trial court's dismissal of physician's claim seeking declaratory relief requiring state medical board to take professional action against doctors participating in lethal injunctions for lack of standing). $C f$. Fons v. Ohio 
State legislatures have also considered the participation of HPs in interrogation. ${ }^{37}$ For example, legislation has been introduced in New York prohibiting HPs from participating in torture or "improper treatment" of detainees, the latter defined as "cruel, inhuman or degrading, treatment or punishment as defined by applicable international treaties and their corresponding interpreting bodies; or cruel and unusual punishment as defined in the United States Constitution or the New York State Constitution."38 The bill would also prohibit HPs from participating "in the interrogation of a prisoner, including being present in the interrogation room, asking or suggesting questions, advising on the use of specific interrogation techniques, monitoring the interrogation, or medically or psychologically evaluating a person for the purpose of identifying potential interrogation methods or strategies." 39 Notably, these are not criminal prohibitions, but rather would authorize the state Office of Professional Discipline, the licensing board, to take action against offending members of the health professions.

In a joint resolution, the California legislature expressed its strong condemnation of the practice of physician participation in enhanced interrogation. The resolution asserts "[t]he United States Department of Defense has failed to oversee the ethical conduct of California-licensed HPs related to torture" and requests the DoD and CIA

\section{remove all California-licensed health professionals from participating in any way in prisoner and detainee interrogations that are}

State Medical Board, 614 N.E.2d 748 (Ohio 1993) (upholding state licensing board's action taken against a doctor based on a violation of AMA Ethics Code); Gladieux v. Ohio State Med. Bd., 728 N.E.2d 459 (Ohio Ct. App. 1999) (upholding state licensing board's discipline of physician for engaging in sexual relationships with patients that violated state statute).

37 See, e.g., A5891, 2011-2012 Gen. Assemb., Reg. Sess. § 2 (N.Y. 2011); H.3361, 187 Gen. Ct., Reg. Sess. (M.A. 2011); S.J. Res. 19, 20072008 Reg. Sess. (Cal. 2008).

38 A5891, 2011-2012 Gen. Assemb., Reg. Sess. $§ 2$ (N.Y. 2011). 
coercive or "enhanced" or that involve torture or cruel, inhuman, or degrading treatment or punishment, as defined by the Geneva Conventions, CAT, relevant jurisprudence regarding $\mathrm{CAT}$, and related human rights documents and treaties.

The Joint Resolution further directed California's health professional licensing agencies to notify HPs

about their professional obligations under international law, specifically Common Article III of the Geneva Conventions, the Convention against Torture and Other Cruel, Inhuman, or Degrading Treatment or Punishment (CAT), and the amended War Crimes Act, which prohibit the torture of, and the cruel, inhuman, and degrading treatment or punishment of, detainees in United States custody [and] that those who participate in coercive or "enhanced" interrogation, torture, as defined by CAT, or other forms of cruel, inhuman, or degrading treatment or punishment may one day be subject to prosecution. $^{40}$

Though this joint resolution passed the California legislature, without the governor's signature, it is not law.

State legislation of this type raises significant constitutional questions outside the scope of this article. For example, while regulation of health care providers is typically considered a state function, as one of many powers reserved to the several states under the Tenth Amendment of the United States Constitution; where national security interests are at issue-including the specific actions of the federal military forces-such state regulation is likely preempted under one of several theories. ${ }^{41}$ The New York

40 Id. (emphasis added).

41 Congress's powers include the power to define and punish offenses against the law of nations, make rules concerning captures on 
legislation noted above recognizes this issue, stating " $[t]$ he legislature is mindful that ordinarily there are limits on New York state's jurisdiction relating to conduct outside the state or under federal authority. However, it is proper for the state to regulate health care professional licensure in relation to a professional's conduct, even where the conduct occurs outside the state. . ." 42

\section{APPLICATION OF LAW AND ETHICAL STANDARDS TO HEALTH PROFESSIONALS' ACTIVITIES}

This section identifies and illustrates the various types of interrogation-related activities in which MHPs have engaged that have become the subject of allegations of misconduct and applies available and applicable law and ethical standards to those types of activity. Where available, real examples of activities alleged to constitute misconduct by HPs are provided. 43 As will be demonstrated, while professional ethical standards are implicated by nearly every interrogation-related activity for which HPs have been criticized, the law is silent on most.

land and water, raise and support the Army, provide and maintain the Navy, and make rules for the government and regulation of the land and naval forces. U.S. CoNST. art I, $\S 8$. And of course, the President has authority as commander-in-chief. Id. at art. II, $\S 2$. For discussion of federal preemption of powers traditionally reserved to the states in the context of national security, see, e.g., E.L. Gaston, Taking the Gloves Off of Homeland Security: Rethinking the Federalism Framework for Responding to Domestic Emergencies, 1 HARV. L. \& POL'Y REV. 519 (2007) ("Federalism preferences must take a backseat to the country's immediate need for a functional preparedness and response system."); Felice Batlan, Law In The Time Of Cholera: Disease, State Power, And Quarantines Past And Future, 80 TEMP. L. Rev. 53 (2007); Alan DERShowitz, PREemption: A KNIFE THAT CuTS BOTH WAYS (2006). One commentator correctly observed the distinction between ethics and law in this area, advocating state legislation proscribing physicians' involvement in interrogation, but ignored completely the possibility such legislation would be unconstitutional or preempted. Bahnassi, supra note 34 .

42 A5891, 2011-2012 Gen. Assemb., Reg. Sess. § 1 (N.Y. 2011).

43 The examples provided are not intended as an exhaustive catalog of all such conduct, nor are the examples provided necessarily the most egregious. 


\section{A. General Involvement in Interrogation Planning and Training}

Participation by MHPs in general detainee interrogation planning and training activities-as opposed to specific interrogations-occurred early in the Global War on Terror ("GWOT"). MHPs were involved in creating the interrogation plans and techniques designed at headquarters, implemented initially at Guantanamo, and subsequently employed elsewhere in the GWOT. Activities included suggesting and opining on specific interrogation methods, including some that would later be called "enhanced interrogation techniques," and providing training to interrogators and other HPs.

\section{Examples: Headquarters-Level General Interrogation Plans and Methods Development}

That the dawn of the United States military's use of "enhanced interrogation techniques" in the GWOT coincided with the dawn of MHPs' involvement in interrogation was not "coincidental." Apparently without being requested to do so, in April 2002, Dr. Bruce Jessen, a psychologist with experience providing interrogation resistance training (that is, defensive rather than offensive interrogation training) in the United States military's Survival, Evasion, Resistance, and Escape ("SERE") training programs drafted an "exploitation plan" for interrogating detainees and provided it to his commander at the Joint Personnel Recovery Agency ("JPRA"). ${ }^{44}$ Dr. Jessen's exploitation plan contained recommendations for JPRA involvement in the detainee exploitation process, including JPRA deploying a core "captivity/exploitation team" under his lead. ${ }^{45}$ That is, Dr. Jessen recommended that he-a psychologist with no

44 S. COMM. ON ARMED SERVICES, 110TH CONG., REP. ON INQUIRY INTO THE TREATMENT OF DETAINEES IN U.S. Custody 14 (Comm. Print 2008) [hereinafter SASC REPORT]. The "Exploitation Draft Plan," which was circulated on April 16, 2002, stated that its objective was to "[h]old, manage and exploit detainees to elicit critical information." Id.

45 Id. 
offensive interrogation experience-direct the United States' interrogation of al Qaeda detainees. Demonstrating awareness there would be legal limitations, but ignorance of the breadth of legal restrictions, the plan included operational principles for exploitation, the "only restricting factor [for which] should be the Torture Convention." 46

Later, when formulating the Bush Administration's enhanced interrogation policy, the DoD General Counsel requested JPRA provide information regarding the longterm psychological effects of interrogation resistance training employing various harsh interrogation techniques. ${ }^{47}$ JPRA turned to the Air Force SERE school's senior psychologist, Dr. Jerald Ogrisseg, for assistance. Dr. Ogrisseg initially demurred, asking whether real world waterboarding would be illegal and noting that "aside from being illegal, it was a completely different arena that we in the Survival School didn't know anything about." 48 Ultimately, Dr. Ogrisseg produced a memorandum that concluded "if there are any long-term psychological effects of [United States Air Force SERE Training], they are certainly minimal," importantly attributing that conclusion to specific efforts the SERE program undertook to minimize the risk of

$46 \quad I d$. at 15.

47 Id. at 29 (referring to Bybee Memo to Gonzales, supra note 10, and Memorandum from Jay S. Bybee, Assistant Att'y Gen., to John Rizzo, Acting Gen. Counsel for the Central Intelligence Agency 9 (Aug. 1, 2002) [hereinafter Bybee Memo to Rizzo], available at http://luxmedia.com.edgesuite.net/aclu/olc_08012002_bybee.pdf).

Ostensibly, this request was to formulate a position regarding the soonto-be created legal position of the Administration regarding whether various techniques caused "significant psychological harm of significant duration, e.g., lasting for months or even years," the standard ultimately articulated in the "Bybee Memo" for determining whether interrogation activities constituted "torture" under 18 U.S.C. $\S \S 2340$ 2340A. Bybee Memo to Gonzales, supra note 10. This memorandum, along with the Bradbury memoranda, was withdrawn by the Office of Legal Counsel ("OLC") on June 11, 2009. Memorandum for the Attorney General from David J. Barron, Acting Assistant Attorney General, Office of Legal Counsel, for the Att'y General, Re: Withdrawal of Office of Legal Counsel Opinion (June 11, 2009) [hereinafter Barron Memo of June 11, 2009], available at http://www.justice.gov/olc/2009/ memo-barron2009.pdf.

48 SASC REPORT, supra note 44, at 29. 
long-term psychological effects, efforts that would be absent when the United States ultimately employed the SERE techniques to interrogate real detainees. ${ }^{49}$

Without Dr. Ogrisseg's knowledge, his memorandum later played a part in the formulation of the so-called "Bybee Torture Memos," issued on August 1, 2002, that provided legal justification for various enhanced interrogation techniques. ${ }^{50}$ Thus, policymaking at the highest level regarding acceptable interrogation activities in the GWOT was directly informed by military psychologists. The fact that policymaking regarding how to interrogate detainees was informed by psychological assessment of the results of counter-resistance training provided to voluntary trainees is a blunder difficult to understand. 51 Even more

49 Id. at 29-30. The Air Force minimized risk to SERE trainees by, among other things:

performing three extensive debriefings during training. Dr. Ogrisseg said that "affording students these opportunities to discuss their training experiences in open group environments mitigates the risk of turning a 'dramatic' experience into a 'traumatic' experience." $\mathrm{He}$ told the Committee that there are numerous controls in place at SERE school to ensure that the training does not become "traumatic" for its students.

Id.

50 Dr. Ogrisseg's memorandum was forwarded to DoD General Counsel's office approximately one week before the two "Bybee Torture Memos" were issued on August 1, 2002. SASC REPORT, supra note 44, at 30 . This memorandum played a part in the formulation of the Bybee Memos' articulation of harm and authorization for certain interrogation techniques. Id. at 31-35. Dr. Ogrisseg was surprised to learn his memorandum had been forwarded to DoD General Counsel because his analysis was produced with volunteer students in mind, not detainees. He later testified to the SASC that the conclusions in his memorandum were "not applicable to the offensive use of SERE techniques against real world detainees." Id. at 30 .

51 In fact, Dr. Ogrisseg later identified seven key differences between the SERE training environment and detainee interrogation. Id. at 31 . Indeed, many of the "physical pressure" techniques used during mock interrogation at SERE training are for the purpose of increasing resistance to interrogation, rather than decreasing it. Id. at 
egregious from a legal standpoint, the SERE training that would be reverse-engineered to become the enhanced interrogation techniques was itself explicitly intended "to replicate harsh conditions that the Service member might encounter if they are held by forces that do not abide by the Geneva Conventions."52

\section{Examples: Guantanamo Interrogation Plan Development}

By Fall 2002, increased high-level pressure was being put on personnel at Joint Task Force 170 ("JTF 170")—the command with responsibility for detention operations at Guantanamo - to produce actionable intelligence from detainee interrogation activities. ${ }^{53}$ This pressure resulted in the creation of a Guantanamo-specific interrogation plan that would ultimately form the basis for interrogation plans at other military detention facilities.

A newly constituted team of HPs created for the specific purpose of assisting interrogations - the Behavioral Science Consultation Team ("BSCTs," colloquially pronounced "biscuits")-played a critical role in the drafting of the Guantanamo interrogation plan. ${ }^{54}$ The first such team was created shortly after the June 2002 arrival of three Army HPs-a psychiatrist, a psychologist, and an enlisted

53 (citing Email from LTC Morgan Banks to MAJ Paul Burney (Oct. 2, 2002)).

52 OFFICE OF THE INSPECTOR GENERAL OF THE DEPARTMENT OF DEFENSE, REVIEW OF DOD-DiRECTED INVESTIGATIONS OF DETAINEE ABUSE 23 (Aug. 25, 2006), available at http://humanrights.ucdavis.edu/ projects/the-guantanamo-testimonials-project/testimonies/testimoniesof-the-defense-department/dod_inspector_general.pdf (emphasis added).

53 Such pressure included direct communications from thenDeputy Secretary of Defense Paul Wolfowitz that "[Guantanamo] should use more aggressive interrogation techniques." SASC REPORT, supra note 44 , at $41 \cdot 42$.

54 MILES, supra note 3, at 53-54. BSCTs were not new creations for the purpose of interrogation at Guantanamo. Rather, they had long existed in the United States military for non-interrogation purposes, such as evaluating service members' suitability for a particular duty, treating combat-related stress, and improving unit morale and cohesion. Id. at 54 . 
psychiatry technician-to Guantanamo. ${ }^{55}$ These HPs whose previous duties had never involved interrogation were thrust without preparation into a non-care role. ${ }^{56}$ Remarkably, none of the new medical providers had any training to support interrogations, though they ultimately attended a short training provided by JPRA "with the expectation they would learn about and bring back interrogation techniques that could be considered for use in interrogations at GTMO."57 By this point, if not earlier, the Rubicon was crossed. No longer was interrogation technique development in the hands of psychologists who were career resistance training specialists; active duty HPs who had deployed expecting to provide medical and psychological care to United States service members were now part of the interrogation team. ${ }^{58}$

Initially, there was no standard operating procedure in place for the BSCT at Guantanamo. By November 2002, a

55 SASC REPORT, supra note 44, at 38 . Though BSCTs initially included psychiatrists, from mid-2003, the positions were usually filled by psychologists. OFFICE OF THE SURGEON GENERAL OF THE ARMY, ASSESSMENT OF DETAINEE MEDICAL OPERATIONS FOR OEF, GTMO, AND OIF 18-2 (Apr. 13, 2005), available at http://humanrights.ucdavis.edu/ resources/library/documents-and-reports/detmedopsrpt.pdf [hereinafter Army Surgeon General Assessment].

56 The circumstances of their arrival illustrate some of the professional confusion detainee interrogation operations causes for medical providers asked to participate in interrogation activities. All three providers were members of the Army's 85th Medical Detachment's Combat Stress Control Team and arrived at Guantanamo erroneously expecting to care for United States service members dealing with deployment-related stress. SASC REPORT, supra note 44, at 38-39.

57 Id.

58 BSCTs would become important elements of interrogation operations at other locations as well. In his 2003 assessment of intelligence problems at Abu Ghraib, Major General Geoffrey Miller, who had commanded JTF-170 at GTMO, identified the lack of a BSCT supporting intelligence operations as a problem, stating BSCTs were "essential in developing integrated interrogation strategies and assessing interrogation intelligence production." GEOFFREY D. MILLER, ASSESSMENT OF DOD COUNTERTERRORISM INTERROGATION AND DETENTION OPERATIONS IN IRAQ (U), 5 (Sep. 9, 2003), available at http://www.dod.mil/pubs/foi/operation_and_plans/Detainee/taguba/ANN EX_020_MG_MILLER_REPORT.pdf. 
written procedure was created that described BSCT tasks as including the following:

consulting on interrogation approach techniques, conducting detainee file reviews to construct personality profiles and provide recommendations for interrogation strategies; observing interrogations and providing feedback to interrogators on detainee behavior, flow of the interrogation process, translator and cultural issues and possible strategies for further interrogation; and providing consultation/training on specific behavioral science interviewing and observational techniques that promote productive interrogation. ${ }^{59}$

The November standard operating procedure stated the BSCT "does not conduct medical evaluation or treatment of detainees and does not participate in determining medical treatment protocols for detainees." 60 This attempt to distinguish HPs engaged in healthcare from those who were not has been a consistent approach of the United States Department of Defense, ultimately culminating in a regulation to that effect, DoDI $2310.08 \mathrm{E}$.

In response to increased political pressure to obtain actionable intelligence, in Fall 2002, the BSCT was directed to draft an interrogation policy that could be formally submitted up the chain of command for review. ${ }^{61}$ Some of the interrogation approaches the BSCT identified in its memorandum came from their brief JPRA training, while other approaches were "simply made up by the BSCT."62 This level of participation by HPs in the planning of interrogation techniques is unusual. Military personnel who just prior to their deployment to Guantanamo had been

59 SASC REPORT, supra note 44, at 39 (citing JTF GTMO-BSCT Memorandum, BSCT Standard Operating Procedures (Nov. 11, 2002)).

60 Id.

61 SASC REPORT, supra note 44, at 50.

62 Id. 
providing medical treatment to United States service members, and who had no experience with interrogation, were now creating the proposed techniques that would become the basis for military use of enhanced interrogation techniques.

In the course of one evening, the BSCT psychiatrist and psychologist produced the BSCT Counter-Resistance Strategy Memorandum, proposing three categories of interrogation techniques to "develop rapport, promote cooperation, and counter resistance." 63 "Category I" techniques included incentives and "mildly adverse approaches" such as telling a detainee that he was going to be at Guantanamo forever unless he cooperated. 64 "Category II" techniques, which included stress positions, the use of isolation for up to 30 days, and hooding, were suggested for "high priority" detainees, defined in the memo as "any detainee suspected of having significant information relative to the security of the United States."65 "Category III" techniques were proposed "ONLY for detainees that have evidenced advanced resistance and are suspected of having significant information pertinent to national security." 66 "Category III" techniques included sleep deprivation and:

the daily use of 20 hour interrogations, the use of strict isolation without the right of visitation by treating medical professionals or the International Committee of the Red Cross (ICRC); the use of food restriction for 24 hours once a week; the use of scenarios designed to convince the detainee he might experience a painful or fatal outcome; non-injurious physical consequences; removal of clothing;

63 Id. at 50-52 (citing Major Paul Burney and [redacted], Memorandum for Record, Counter-Resistance Strategies (Oct. 2, 2002) [hereinafter BSCT Counter-Resistance Strategies Memorandum]).

$64 \quad I d$. at 51.

65 Id. at 52 (quoting BSCT Counter-Resistance Strategies Memorandum, supra note 63 , at 2 ).

$66 \quad I d$. at 52. 
and exposure to cold weather or water until such time as the detainee began to shiver. ${ }^{67}$

The BSCT's discomfort with some of the techniques they included in their own memorandum highlights the tension HPs face when assigned to participate in interrogation activities. The Counter-Resistance Strategy Memorandum contained language in which the BSCT disclaimed some of the very techniques offered:

Experts in the field of interrogation indicate the most effective interrogation strategy is a rapport-building approach. Interrogation techniques that rely on physical or adverse consequences are likely to garner inaccurate information and create an increased level of resistance. . . . The interrogation tools outlined could affect the short term and/or long term physical and/or mental health of the detainee. Physical and/or emotional harm from the above techniques may emerge months or even years after their use. It is impossible to determine if a particular strategy will cause irreversible harm if employed. 68

The BSCT Counter-Resistance Strategies Memorandum was immediately discussed in a meeting at Guantanamo

67 Id. at 52 (quoting BSCT Counter-Resistance Strategies Memorandum, supra note 63 , at 4-5). In addition to specific interrogation techniques, the memorandum made recommendations for the treatment of detainees in the cell blocks, specifically proposing that "resistant detainees might be limited to four hours of sleep a day; that they be deprived of comfort items such as sheets, blankets, mattresses, washcloths; and that interrogators control access to all detainees' Korans." Id. The memorandum also described using white noise as a form of psychological pressure and advocated that "all aspects of the [detention] environment should enhance capture shock, dislocate expectations, foster dependence, and support exploitation to the fullest extent possible." Id.

68 Id. at 52 (quoting BSCT Counter-Resistance Strategies Memorandum, supra note 63). 
that included command-level personnel and several lawyers, including both the Staff Judge Advocate (senior military attorney) for JTF-170 and a CIA attorney. 69 According to the meeting minutes, the BSCT representative offered that psychological stressors such as "sleep deprivation, withholding food, isolation, and loss of time" were "extremely effective" and identified "camp-wide, environmental strategies designed to disrupt cohesion and communication among detainees" as potentially helpful to improve the effectiveness of interrogations and explained that the detention "environment should foster dependence and compliance."70

Ultimately, the BSCT-drafted, three-category approach to increasing interrogation methods, which itself was based on what BSCT members had learned from their interaction with JPRA regarding SERE counter-resistance training, became the basis for the Guantanamo interrogators' request for approval of more aggressive interrogation techniques that was forwarded to the Pentagon. ${ }^{71}$

69 Email from Thomas Blane to Sam McCahon, FW: Counter Resistance Strategy Meeting Minutes (Oct. 24, 2002, 7:57 PM), available at http://www.torturingdemocracy.org/documents/20021002. pdf) [hereinafter Counter-Resistance Strategy Meeting Minutes]. During the meeting, the BSCT briefer reiterated that rapport building and the "friendly approach" were proven to "yield positive results," while "fear based approaches" were "unreliable" and "ineffective in almost all cases." Id. Unfortunately, "despite BSCT comments on the effectiveness of rapport building, the meeting minutes reflect little discussion of that approach." SASC REPORT, supra note 44, at 54.

70 FW: Counter-Resistance Strategy Meeting Minutes, supra note 69. After the meeting, the BSCT psychiatrist remained actively involved in preparation of more aggressive interrogation tactics, including attempts to find training opportunities for interrogators. SASC REPORT, supra note 44, at 57. The psychiatrist contacted another headquarters, reporting that "were more aversive techniques approved for use in the future by appropriate people, the operation would like to have a few task force personnel specifically trained in various techniques." Id. (quoting email from Major Paul Burney to Lieutenant Colonel Morgan Banks (Oct. 4, 2002) (internal quotes omitted)).

71 Interrogators requested permission from JTF-170 commander Major General Dunlavey to use counter-resistance interrogation techniques. SASC REPORT, supra note 44 , at 61 . The request memorandum "was largely drawn from the October 2, 2002[,] 
In fact, the Guantanamo-specific interrogation techniques initially drafted by the BSCT psychiatrist and psychologist were ultimately borrowed and employed by interrogation operations elsewhere, including in Afghanistan and Iraq. ${ }^{72}$ The widespread adoption of the interrogation procedures is extraordinary, not only because it was based on a memorandum initially prepared by a psychiatrist and psychologist, but also because of the differences in legal status of detainees in Guantanamo, Afghanistan, and Iraq. Thus, interrogation approaches initially authorized for a "war on terror" taking place largely in Afghanistan and at Guantanamo -- a war to which the President had erroneously determined the protections of the Geneva Conventions did not apply-would

memorandum that the Guantanamo [BSCT] had written upon their return from the JPRA training at Fort Bragg." Id. In fact, the memorandum contained the same three-category approach and virtually the same techniques originally described in the BSCT's CounterResistance Strategy Memorandum. Id. Notably, two of the Category III techniques in this request memorandum-the use of phobias and the use of the "wet towel and dripping water" (i.e., "waterboarding") to induce the misperception of suffocation-were not derived from the BSCT Counter-Resistance Strategy Memorandum.

72 Contemporaneous to drafting the BSCT Counter-Resistance Strategy Memorandum, the Guantanamo BSCT briefed visitors from the Special Mission Unit ("SMU") Task Force ("TF") assigned to interrogations in Afghanistan (SMU TF-Afghanistan). SASC REPORT, supra note 44 , at 149 . Ultimately, the SMU TF-Afghanistan Interrogation standard operating procedure contained interrogation techniques from the Guantanamo BSCT memorandum and was "influenced" by it. Id. at 153-54. In 2006 the Department of Defense Inspector General concluded that the SMU SOP "was influenced by the counter-resistance memorandum that the Secretary of Defense approved on December 2, 2002," which was itself based on the BSCT Counter-Resistance Strategy Memorandum. Likewise, the SMU TF in Iraq's (SMU TF-Iraq) interrogation policy, in place before the beginning of OIF, was identical to the February 2002 policy in use by the SMU TFAfghanistan and "reflected the influence of techniques authorized for use at GTMO." Id. at 158. Ultimately, techniques identified in proposed interrogation policy at $\mathrm{Abu}$ Ghraib can be traced back to techniques authorized for use at Guantanamo by Secretary Rumsfeld in December 2002, which were based on the BSCT Counter-Resistance Strategy Memorandum authored by a psychiatrist and psychologist. Id. at 170 . 
ultimately be authorized for all United States interrogations in Iraq, where the Geneva Conventions clearly did apply.

It is important to note that ultimately another health professional helped bring about the end of the approved military use of Category II and Category III interrogation techniques at Guantanamo. Navy Criminal Investigative Service Chief Psychologist Michael Gelles blew the whistle on the techniques by meeting with Navy General Counsel Alberto Mora, explaining how the techniques were being used at Guantanamo. ${ }^{73}$ Ultimately, after significant efforts by Mr. Mora, on January 15, 2003, Secretary of Defense Rumsfeld withdrew approval for use of Category II and Category III techniques. ${ }^{74}$

\section{Examples: General Interrogation Training}

Military medical provider involvement in interrogation training also began early in the GWOT. In fact, military psychologists were among the first to prompt discussion of how to overcome detainee resistance to interrogation techniques and prepared a paper on al Qaeda counterresistance techniques for use by United States interrogators, a report that resulted in interrogators receiving training to overcome such techniques. ${ }^{75}$ In March 2002, Dr. Bruce Jessen, the senior SERE psychologist at JPRA who had suggested he direct interrogation of detainees, was part of a two-person team that trained

73 SASC REPORT, supra note 44 , at 106.

74 Id. at 107-08. After meeting with Dr. Gelles, in January 2003, and after consulting with other DoD legal personnel, Mr. Mora expressed his concerns to DoD General Counsel Haynes. Id. at 106. In a dramatic encounter, on January 15, 2003, Mr. Mora provided a copy of a draft memorandum from him to Mr. Haynes that opined that "the majority of the proposed category II and all of the proposed category III techniques were violative of domestic and international legal norms in that they constituted, at a minimum, cruel and unusual treatment and, at worst, torture." Id. at 108. Mr. Mora told Mr. Haynes he would sign the draft memorandum unless Secretary Rumsfeld withdrew approval for Category II and Category III techniques that day. Id.

75 Id. at 6-7. 
interrogators headed to Guantanamo and Afghanistan. ${ }^{76}$ The training, called "Al Qaeda Resistance Contingency Training," described methods used by al Qaeda to resist interrogation and exploitation and countermeasures to defeat those methods. ${ }^{77}$ This training included "isolation and degradation," "sensory deprivation," "physiological pressures," and "psychological pressures."78 Additionally, one military intelligence analyst at Guantanamo reported that "the notion of using sexual gambits to unnerve detainees was promoted by 'the BSCTs, who were these psychiatrists and psychologists from Fort Bragg." 79 By September 2002, psychologists were training not only interrogators, but also other military psychologists assigned to Guantanamo. ${ }^{80}$

76 Id. at 8-9. JPRA psychologists were involved in training not only military interrogators, but "other government agency" interrogators at various points in 2002, which training "suggested 'exploitation strategies." Id. at 19-20 (quoting Memo from Colonel John Prior II to JPRA/CC (Colonel Randy Moulton), Request from [Redacted] for Interrogation Training Support (Jun 20, 2002)). Though redacted, from the context of the references and redactions, it appears the "other government agency" was the CIA. Such activities mean MHPs were at least indirectly involved in "other government agency" interrogation of al Qaeda detainees that otherwise had no tie to military activities. In fact, the senior SERE psychologist was detailed to the "other government agency" in July 2002. Id. at 23-24.

77 Id. at 8-9.

78 Id. at 9. Dr. Jessen's after-action report indicated the training provided suggestions on "how to exploit al Qaeda detainees for intelligence within the confines of the Geneva Conventions." Id. at 10. However, Dr. Jessen later testified before the SASC that he would "not have known at the time if isolation, degradation, sensory deprivation, or other topics referenced in the slides would have been within the confines of the Geneva Conventions." Id. at 11.

79 Jane Mayer, The Experiment, THE NEW YoRKER, July 11 \& 18, 2005 , at 60,65 .

80 In September 2002, the then senior SERE psychologist, Dr. Gary Percival, along with non-medical interrogation instructors, trained Army psychologists assigned to GTMO in "exploitation from a SERE perspective." SASC REPORT, supra note 44, at 44 . It should be noted that throughout the course of the GWOT, various personnel within JPRA and at command echelons above JPRA objected to JPRA's involvement in training interrogators. One particularly candid assessment came from the Staff Judge Advocate ("SJA") (senior lawyer) 


\section{Application of Law and Ethical Standards to General Interrogation Involvement}

\section{a. Law}

Simply stated, the act of HPs planning interrogations or providing training in interrogation methods does not itself constitute a violation of any international or domestic law. In fact, no international or domestic law prohibits anyone's involvement in general interrogation planning or interrogation training, let alone specifically forbids HPs' involvement. Given the absence of law proscribing general planning and training, such activities could only become a

at Joint Forces Command ("JFCOM"), JPRA's higher headquarters. The SJA stated:

[I]t is not advisable to have JPRA assist in "improving exploitation" (i.e., suggesting more effective interrogation techniques). JPRA's core expertise is in training DoD personnel to resist/cope with techniques many of them illegal that may be employed by our enemies if DoD personnel are captured. It just doesn't make sense to me to have experts in what the "bad guys" do to us advising our U.S. interrogators. . .

Id. at 227 (quoting Email from Captain Dan Donovan to Admiral Edmund Giambastiani, JFCOM Commander (May 13, 2004)). Additionally, a SERE psychologist poignantly observed:

[W] e need to really stress the difference between what instructors do at SERE school (done to INCREASE RESISTANCE capability in students) versus what is taught at interrogator[ school (done to gather information). What is done by SERE instructors is by definition ineffective interrogator conduct, and interrogator school, not SERE school is the appropriate focus and model for investigating interrogators. Simply stated, SERE school does not train you on how to interrogate, and things you "learn" there by osmosis about interrogation are probably wrong if copied by interrogators.

Id. at 229 (quoting email from Lieutenant Colonel Richard Posey to Major Paul Voss, (July 12, 2004)). 
violation of law if the subsequent interrogations themselves violate the law, thereby implicating those involved in planning and training through some theory of secondary liability. Whether MHPs' activities give rise to accomplice liability requires analysis complicated by the variety of jurisdictions that could apply it. ${ }^{81}$ In any event, whether

81 Significant differences among jurisdictions are especially noticeable regarding the mental element (mens rea). United States federal courts generally follow the Model Penal Code and require that an accomplice act with the purpose of promoting or facilitating the offense. That is, whether the purported accomplice "associated himself with the venture" or sought "by his action to make it succeed." See Nye \& Nissen v. United States, 336 U.S. 613, 618-19 (1949). It is important to acknowledge that despite Supreme Court precedent, federal case law on this issue is not as simple as this general summary suggests. See Baruch Weiss, What Were They Thinking?: The Mental States of the Aider and Abettor and Causer Under Federal Law, 70 FORDHAM L. REV. 1341, 1350-52 (2002). Various states, however, have differing mens rea requirements. See, e.g., John Decker, The Mental State Requirement for Accomplice Liability in American Criminal Law, 60 S.C. L. REV. 237 (2010) (comparing states' approaches). Further, if the matter were being determined by a foreign court under universal jurisdiction (for example, in the prosecution of a "grave breach" of the Geneva Conventions), it is entirely unclear which standard would be used. International tribunals have historically applied the knowledge (rather than purpose) standard, which only requires the accomplice be reasonably aware their actions would facilitate the ultimate offense, but other international law suggests a purpose standard might apply. See, e.g., Trial of Bruno Tesch and Two Others, 1 War Crimes Comm'n, U.N. Law Reports of Trials of War Criminals 93 (1947) (British Military Court Hamburg, Germany) (finding defendants guilty of knowingly providing chemicals used in Nazi gas chambers); Prosecutor v. Aleksovski, Case No. IT-95-14/1-A, Judgment, Iף 61, 79-80 (Int'l Trib. for the Former Yugoslavia Mar. 24, 2000); Prosecutor v. Furundzija, Case No. IT-95-17/1-T, Judgment, ๆ 1 245-46 (Int'l Trib. for the Former Yugoslavia Dec. 10, 1998). However, while one Rome Statute provision on complicity requires purpose, a second provision governing complicity in collective criminality requires only knowledge of the underlying offense. Compare Rome Statute of International Criminal Court art. 25(3)(c), July 17, 1998, 2187 U.N.T.S. 90 ("for the purpose of facilitating the commission") with art. 25(3)(d)(ii) (contributions made "in the knowledge of the intention of the group to commit the crime"). The second provision is arguably most applicable to HPs who provided assistance not to a single individual but to multiple individuals acting with a "common purpose" to torture or unlawfully degrade detainees. But see Presbyterian Church of Sudan v. Talisman Energy, Inc., 582 
MHPs' participation in general plans and methods development violated law rests not on any law specific to HPs, but rather on accomplice liability applicable to anyone.

\section{b. Ethics}

In the area of general participation in interrogation planning and training, international and domestic ethical standards are somewhat less restrictive than in other areas discussed in the following sections. No international or domestic ethical standard outright prohibits participation in general interrogation planning and training and some explicitly allow such participation. According to some ethicists, medical personnel "should not be party to interrogation practices contrary to human rights law or the laws of war, and their role in legitimate interrogation should not extend beyond limit setting, as guardians of detainees' health." 82 But where does the line between "limit setting" and participation lie?

The U.N. Principles of Medical Ethics prohibit physicians from applying their knowledge in order to assist in the interrogation of detainees "in a manner that may adversely affect the physical or mental health or condition of such ... detainees and which is not in accordance with the relevant international instruments." 83 Likewise, the WMA Regulations in Times of Armed Conflict state it is unethical for physicians to "employ scientific knowledge to imperil health." Thus, these international ethical standards arguably constrain physicians' participation in general interrogation planning or training no more than law, assuming interrogation techniques that adversely affect the physical or mental health of the detainee are already proscribed by law. ${ }^{84}$ Under these standards, where

F.3d 244, 259 (2d Cir. 2009) (addressing a recent Alien Tort Statute case and concluding that international criminal law follows the purpose standard).

5 .

82 M.G. Bloche \& J.H. Marks, Doctors Go To War, supra note 10, at

83 U.N. Principles of Medical Ethics, supra note 27, para. 4.

84 Of course, this is the subject of intense debate. 
techniques are legal but adversely affect health, HPs could not participate.

On the other hand, as revised in 2006, the Declaration of Tokyo explicitly forbids physicians from using their knowledge to "facilitate any interrogation, legal or illegal." 85 Whether this applies to general interrogation planning is unclear, but providing general strategy and training arguably constitutes "facilitation," at least indirectly. Thus, as of the later-revised Declaration of Tokyo, the types of planning and training activities in which MHPs engaged early in the GWOT were "unethical."

Interestingly, the domestic ethical standards of both the AMA and the American Psychiatric Association leave open the possibility of giving general advice on interrogation strategy and training to military and civilian personnel in either law enforcement or intelligence branches, so long as the interrogations are "humane and respectful of individuals' rights" and do not "threaten or cause physical injury or mental suffering" (in the case of physicians of the AMA) 86 or are related to providing interrogators with training on the "possible medical and psychological effects of particular techniques and conditions of interrogation" (in the case of psychiatrists of the American Psychiatric Association). ${ }^{87}$ This allowance is premised on the idea that professionals' involvement will lead to interrogation techniques that are safer for those being interrogated.

In contrast to the ethical standards for medical doctors, the APA only constrains members from providing support, advice or training "in torture, cruel, inhuman, and degrading treatment," or in settings where persons are held outside of or in violation of international law or the United States Constitution. ${ }^{88}$

85 Revised Declaration of Tokyo, supra note 27 (emphasis added).

86 AMA Opinion 2.068, supra note 29, para. 4.

872006 Position Statement, supra note 30 , para. 3.

882006 APA Resolution Against Torture, supra note 32; 2008 APA Resolution Against Torture, supra note 33; APA Members Approve Petition Resolution on Detainee Settings, AM. PSYCHOL. AsS'N (Sept. 17, 2008), http://www.apa.org/news/press/releases/2008/09/detaineepetition.aspx [hereinafter APA Resolution on Detainee Settings]. Even this proscription suggests as many questions as it answers. When a 
Thus, except for the Declaration of Tokyo, most international and domestic ethical standards permit HPs to participate in general interrogation plans and methods development and training, so long as it does not adversely affect health or get specific to individual detainees (for doctors) and so long as the interrogation does not constitute "torture, cruel, inhuman, and degrading treatment" (for psychologists). That is, as it relates to general interrogation involvement, ethical standards appear to be not much more restrictive than the law.

\section{B. Direct Involvement in Specific Interrogation}

MHPs were directly involved in specific interrogations, including planning the interrogations, consulting during interrogations, conducting pre- $^{-}$and post-interrogation medical and mental health assessments, and, according to some commentators, conducting medical experiments on detainees.

In fact, this direct involvement was institutionalized by policy fairly early in the GWOT when then-Secretary of Defense Donald Rumsfeld issued a memorandum detailing twenty-four authorized techniques for interrogating "unlawful combatants" at Guantanamo, and specifically required such techniques be used only when, inter alia, "the detainee is medically . . . evaluated as suitable" and "a specific interrogation plan (including reasonable safeguards ... and the presence or availability of qualified medical personnel) has been developed." 89 Techniques authorized in

psychologist provides general advice about various interrogation techniques, does the mere discussion of a technique constitute support? What if the health professional discusses a variety of interrogation techniques, some of which are torture and others are not, and the interrogators later determine to use the torturous techniques? Is a simple disclaimer by the psychologist regarding certain techniques sufficient to absolve him or her of guilt under this ethical standard or from accomplice liability under the law?

89 Rumsfeld Approval Memorandum of April 2003, supra note 10. Additionally, Secretary Rumsfeld specifically referenced required "medical and psychological review" when isolation was to be used as an interrogation technique. Id. 
this memorandum included benign interrogation methods such as "asking straightforward questions," but also included, and thus required medical evaluation for, sleep deprivation, isolation, and environmental manipulation. ${ }^{90}$

It is when we turn from general interrogation planning and training to specific interrogation advice that the chasm between law and professional ethics widens. As with general interrogation involvement, there is no international or domestic law that per se prohibits HPs from being directly involved in specific interrogations. Despite the absence of law, there are a significant number of professional ethics pronouncements on HPs' involvement in interrogations.

\section{Examples: Specific Interrogation Planning - Interrogation of Mohammed al-Qahtani}

Little information regarding specific interrogations or specific interrogation planning is publicly available. Despite having fairly detailed information regarding the Qahtani interrogation, it is unclear to what extent the Guantanamo BSCT or other military providers participated in creating the specific interrogation plan for Mohammed Qahtani, though it is clear the generalized interrogation methods at Guantanamo created by the BSCT (discussed above) formed the basis of the specific plan proposed for Qahtani. 91 The involvement of HPs has been explicitly

90 Id. Moreover, the Bush Administration incentivized interrogators to include HPs by offering interrogators a defense to prosecution for torture if they "could show that [they] acted in good faith by taking steps such as surveying professional literature, consulting with experts, or reviewing evidence gained from past experience." Bybee Memo to Gonzales, supra note 10 , at 8.

91 Though it is unclear to what extent the Guantanamo BSCT team participated in devising the interrogation plan for Qahtani and the subsequent request for approval to use aggressive interrogation techniques, at least one military psychologist reviewed the plan and objected. On November 22, 2002, Naval Criminal Investigative Service ("NCIS") Chief Psychologist Michael Gelles formally reviewed the draft plan and stated "[s]trategies articulated in the later phases reflect techniques used to train US forces in resisting interrogation by foreign enemies. . . . [These techniques] would prove not only to be ineffective 
acknowledged by a senior military officer. ${ }^{92}$ Ultimately, between November 23, 2002 and January 16, 2003, Qahtani was subjected to waterboarding, stripping, forced grooming, invasion of space by a female interrogator, being treated like an animal, placed in close proximity to a military working dog, and being forced to pray to an idol shrine,

but also border on techniques and strategies deemed unacceptable by law enforcement professionals. ..." SASC REPORT, supra note 44, at 8081 (quoting Memorandum from Michael G. Gelles to Mark Fallon, Review of JTF-GTMO Interrogation Plan Detainee 063 (Nov. 22, 2002) [hereinafter Gelles Review of JTF-GTMO Interrogation Plan Detainee 063]. He further suggested that if the plan were implemented he would testify as an expert against the proponents of the interrogation. Id.at 81.

92 The commander of United States Southern Command ("SOUTHCOM"), General James T. Hill, later acknowledged the input of medical providers when describing the origin of the aggressive interrogation techniques used in the Qahtani interrogation from late 2002 to early 2003 :

The staff at Guantanamo working with behavioral scientists, having gone up to our SERE school and developed a list of techniques which our lawyers decided and looked at, said were OK. I sent that list of techniques up to the Secretary [of Defense] and said, in order for us to get at some of these very high-profile, high-value targets who are resistant to techniques, I may need greater flexibility. . . And we began to use a few of those techniques, a few of those techniques on this individual. . . .

General James T. Hill, Commander, U.S. Southern Command, Media Availability with Commander, U.S. Southern Command General James T. Hill (June 3, 2004) (transcript available at http://www.defense.gov/transcripts/transcript.aspx?transcriptid=3153).

SOUTHCOM is the DoD's combatant command with responsibility over Guantanamo. SOUTHCOM Component Commands \& Units, U.S S. COMMAND, http://www.southcom.mil/aboutus/Pages/Our-Team.aspx (last visited Dec. 23, 2013). In fact, as demonstrated above, General Hill's characterization that Guantanamo staff "worked with" behavioral scientists understated the behavioral scientists' input-they had actually drafted the initial memo that became the basis for the request for more aggressive interrogation practices that was ultimately forwarded to the Secretary of Defense for approval. Hill, supra. 
techniques bearing a striking resemblance to methods employed at SERE schools. ${ }^{93}$

\section{a. Law}

No international or domestic law prohibits HPs from being involved in specific interrogation planning. However, HPs should note that there is a risk that such activities could incur accomplice liability if the planned interrogation techniques used are illegal, and that risk is greater than in general interrogation planning. When MHPs recommend specific interrogation techniques for use with specific detainees, the actus reus and mens rea elements of accomplice liability are even more clearly established than when involved in general interrogation planning. That is, providing advice constitutes "aid" in the ultimate use of the illegal interrogation technique. ${ }^{94}$ The health professional providing the advice has both the knowledge of the primary act and the purpose to assist the interrogator in performing it. The only question becomes whether the primary actus reus is met; that is, whether the recommended interrogation technique itself constitutes a violation of law.

\section{b. Ethics}

The ICRC has charged HPs at Guantanamo were engaged in "a flagrant violation of medical ethics" by "participating in planning for interrogations." 95 As with general interrogation planning, though most international ethical standards prohibit physicians from applying their knowledge in order to assist in the interrogation of

93 SASC REPORT, supra note 44, at 88-89 (citing a memo of unknown authorship: Methods Employed X-Ray Interrogation ISN 63 (Jan. 17, 2003)).

94 The analysis of the accomplice's actus reus becomes more complicated when the health professional participates in the planning but neither recommends nor discourages use of a particular illegal technique.

95 Neil A. Lewis, Red Cross Finds Detainee Abuse in Guantánamo, N.Y. TIMES (Nov. 29, 2004), http://www.nytimes.com/2004/11/30/politics/ 30gitmo.html?_r=1. 
detainees in a manner deleterious to the detainee's physical or mental health, the Declaration of Tokyo, as revised in 2006, explicitly forbids physicians' use of their knowledge to facilitate any interrogation. ${ }^{96}$ And under the 2006 standards of both the AMA and American Psychiatric Association, physicians must not give advice on specific interrogation techniques for specific detainees, regardless of the nature or legality of the techniques. ${ }^{97}$

Guidance for psychologists is less restrictive, allowing participation so long as interrogation methods do not constitute torture or cruel, inhuman, or degrading treatment. 98 Thus, in the example discussed above involving the specific planning of the Qahtani interrogation, under current standards (not in force at the time the Qahtani interrogation was planned), physicians would be ethically required to not participate at all, while psychologists would be permitted to participate, so long as the methods used did not constitute torture or cruel, inhuman, or degrading treatment. ${ }^{99}$

\section{Examples: Intra-Interrogation Consultation}

Not surprisingly, specific interrogation planning extended into intra-interrogation consultation (i.e., consultation during interrogation sessions). In fact, BSCT operating procedure explicitly called for such

96 U.N. Principles of Medical Ethics, supra note 27; WMA Regulations in Times of Armed Conflict, supra note 27; Revised Declaration of Tokyo, supra note 27.

97 AMA Opinion 2.068, supra note 29, para. 2; 2006 Position Statement, supra note 30 , at para. 3.

982006 APA Resolution Against Torture, supra note 32; 2008 APA Resolution Against Torture, supra note 33; APA Resolution on Detainee Settings, supra note 88 . Of course, this raises the question of whether a psychologist has committed a breach when providing general interrogation advice for use of permitted techniques that is subsequently used by an interrogator in addition to impermissible techniques.

99 Of course, several of the techniques planned for use during the Qahtani interrogation did constitute torture or cruel, inhuman, or degrading treatment, including waterboarding and forced nudity. 
involvement. ${ }^{100}$ Intra-interrogation consultation occurred in two ways: with the providers being physically present at the interrogation and when the providers were physically removed from the interrogation activities, but available for consultation throughout the process.

Because most interrogation logs have not been declassified, obtaining details of health professional attendance at interrogation sessions is difficult. Though Secretary Rumsfeld's interrogation directive required "presence or availability of qualified medical personnel," it is unclear how frequently medical personnel were "present" rather than merely "available." Nevertheless, a few examples exist.

Presence of HPs during the Qahtani interrogation is demonstrated by the interrogation log that shows medical personnel intravenously administered three bags of saline during one session. ${ }^{101}$ Further, statements made by HPs involved in the Qahtani interrogation are sufficiently specific to suggest their physical proximity to the interrogation activities. ${ }^{102}$

Evidence of other instances when HPs where present for interrogations exists, though details are sparse. For

100 SASC REPORT, supra note 44, at 31.

101 MILES, supra note 3, at 61. Notably, administration of this quantity of fluid caused Qahtani to urinate in his pants. Id; see also PhIllipPe SANDS, TORTURE TEAM: RUMSFELD's MEMo AND THE BETRAYAL OF AMERICAN VALUES 170-72 (2008) (asserting Qahtani's interrogation was conducted with a battery of medical-health personnel in attendance and that these personnel "treatled] [Qahtani] for the effects" of the brutal interrogation techniques for the purpose of furthering additional harsh interrogation).

102 For example, a Guantanamo BSCT psychiatrist who participated in the interrogation stated Qahtani was "made [to] believe he was sent to a hostile country which advocated torture" and was also "led to believe he himself might be killed if he did not cooperate with questioning." SASC REPORT, supra note 44, at 88 (quoting Written Statement of [Redacted] (August 21, 2007)). Further, he testified a dog was brought into the Qahtani interrogation during late November or early December an estimated "half dozen times" and the "dog was never allowed to bite the detainee but would be ordered to bark loudly close to the detainee, to sort of sniff or muzzle the detainee, to put paws up on the detainee," information he was unlikely to have absent actual presence at the interrogation. Id. at 90-91. 
example, the "Command Psychologist" at Combined Joint Special Operation Task Force-Arabian Peninsula stated "I sit in on random interrogations." 103 Additionally, though the details of the interrogation, and thus the extent of the provider's activities, remain classified, it is clear from the SASC Report that retired United States Air Force SERE psychologist Dr. James Mitchell was physically present during the CIA's interrogation of Abu Zubaydah. ${ }^{104}$

Perhaps the best evidence of the systematic way in which BSCT members participated in interrogations at Abu Ghraib came directly from Colonel Larry James, the Army psychologist sent there to help rehabilitate the facility in the wake of the stunning documented abuses. "The orders from the general, myself, and the intel center director were crystal clear: if the [BSCT] was not present, there would be no interrogations." 105

Unfortunately, even sparser than evidence that HPs were physically present during interrogation is evidence of what they did, making it impossible to judge whether such activity was illegal.

Even when not present during interrogation, HPsusually members of a BSCT-have been routinely consulted regarding interrogations, with interrogators seeking advice regarding how to proceed. For example, during the extended interrogation of Mohamadou Walid Slahi, interrogators became concerned about Slahi's report that he was hearing voices. 106 One interrogator emailed a Guantanamo BSCT psychologist, asking, "[I]s this something that happens to people who have little external stimulus such as daylight, human interaction etc????

103 Sworn Statement of [name redacted] (Jul. 12, 2004); U.S. ARMY CRIMINAL INVESTIGATION COMMAND, DEP'T OF THE ARMY, CID REPORT OF INVESTIGATION - FINAL - 0189-04-CID259-8023315C213/5Y2E/5X1/5M3A, 14 (Jul. 20, 2004), available at http://www.aclu.org/files/projects/foiasearch/pdf/DODDOACID000545.pd f.

104 SASC REPORT, supra note 44, at 17.

105 LARRY C. JAMES, FIXING HELL: AN ARMY PSYCHOLOGIST CONFRONTS ABU GHRAIB 131 (2008).

106 SASC REPORT, supra note 44, at 140. 
Seems a little creepy."107 The psychologist responded that "sensory deprivation can cause hallucinations, usually visual rather than auditory, but you never know. ... In the dark you create things out of what little you have. . .."108 Whether the psychologist took steps to discourage further sensory deprivation in this instance is unknown. ${ }^{109}$

In another case, an interrogator reported that a BSCT doctor, having read the medical file of a detainee, suggested the inmate's longing for his mother could be exploited to persuade him to cooperate. ${ }^{110}$ Though details remain classified, Vice Admiral Church's investigation and report confirmed HPs "observe[d] interrogations, assess[ed] detainee behavior and motivations, review[ed] interrogation techniques, and offer[ed] advice to interrogators." 111 Finally, a BSCT psychologist apparently insisted interrogators deprive Qahtani of sleep during the extended course of his interrogation. ${ }^{112}$

One recent approach to attacking MHPs' involvement in detention-based interrogation operations has been to label their activities as "medical experiments." Several commentators have vigorously urged the United States MHPs engaged in human experimentation on detainees at Guantanamo and other locations. ${ }^{113}$ However, it is unclear

107 Id. at 140-41 (quoting Email from JTF-GTMO Interrogator to LTC Diane Zierhoffer (Oct. 17, 2003)).

108 Id. at 141 (quoting Email from JTF-GTMO Interrogator to LTC Diane Zierhoffer (Oct. 17, 2003)).

109 Unfortunately, the full text of the emails between the interrogator and the BSCT psychologist cited by the SASC REPORT, supra note 44 , is not publicly available.

110 Neil Lewis, Interrogators Cite Doctors' Aid at Guantanamo Prison Camp, N.Y. TIMES, June 24, 2005, http://www.nytimes.com/2005/ 06/24/politics/24gitmo.html?ex=1277265600\&en=b1960558c2ad9fa4\&ei $=5088 \&$ partner $=$ rssnyt\&emc $=r s s$ [hereinafter Lewis, Interrogators Cite Doctors' Aid].

111 A.T. ChURCH, III, OFFICE OF THE SEC'Y OF DEF., REVIEW OF DEPARTMENT OF DEFENSE DETENTION OPERATIONS AND DETAINEE INTERROGATION TECHNIQUES (U), Executive Summary (2005) [hereinafter Church Review], available at http://www.aclu.org/ images/torture/asset_upload_file625_26068.pdf.

112 See Mayer, supra note 79, at 68.

113 See, e.g., Brennan, Torture of Detainees, supra note 3, at 103340 (2011); MILES, supra note 3, at 50-59; and PHYSICIANS FOR HUMAN 
what such commentators mean by "experimentation" and thus the factual support for this allegation is difficult to confirm or disprove. ${ }^{114}$ Professor David Brennan vigorously charges HPs were involved in human subject experimentation, but only vaguely refers to which conduct constituted experimentation, stating "[t]he activity by medical health personnel described in the preceding passages was prohibited conduct, as defined by domestic and international law." Unfortunately, the "preceding passages" constitute a meandering explication of legal and ethical standards and various alleged abuses, most of which do not explicitly deal with HPs or with medical experiments, leaving which practices constituted "experiments" unclear. ${ }^{115}$

In the medical legal context, "experiment" has a specific meaning that is inapplicable to the minimal facts commentators have asserted to support their claims that medical experimentation occurred at United States detention facilities. Though he alleges United States HPs "fulfilled the same role as the Nazi doctors," Professor Brennan ignores the fact that the Nazi doctors completely designed and controlled the entire experiment process and the infliction of harm on subjects was for the purpose of learning the human body's tolerance of or reaction to

RIGHTS, EXPERIMENTS IN TORTURE: EVIDENCE OF HUMAN SUBJECT RESEARCH AND EXPERIMENTATION IN THE "ENHANCED" INTERROGATION PROGRAM (Jun. 2010) [hereinafter PHR, EXPERIMENTS IN TORTURE], available at https://s3.amazonaws.com/PHR_Reports/Experiments_in_ Torture.pdf.

114 Some of Guantanamo's own military nomenclature may have contributed to the idea that interrogation involved experiments-JTF170 was called the "Battle Lab" by consecutive general officers commanding JTF-170. SASC REPORT, supra note 44, at 43. However, even those who objected to this term understood it to refer to the idea that "interrogations and other procedures were to some degree experimental, and their lessons would benefit $\mathrm{DoD}$ in other places." Id. This was not intended to connote that medical experiments were occurring at Guantanamo.

115 Brennan, Torture of Detainees, supra note 3, at 1033. Indeed, Professor Brennan provides virtually no details regarding what he contends constituted "medical experiments." Id. 
harm. ${ }^{116}$ Likewise, the Physicans for Human Rights' ("PHR") paper purporting to show the United States engaged in experimentation on interrogated detainees misses the crucial distinction between what the United States is alleged to have done-collecting data about various interrogation methods-and real human subject experimentation: purpose. ${ }^{117}$

In arguing for more international law governing them, renowned international law scholar M. Cheriff Bassiouni offered one broad definition of medical experiments: "anything done to an individual to learn how it will affect him. Its main objective is the acquisition of new scientific

116 Specific medical experiments for which Nazi medical personnel were convicted, included: 1) High-altitude experiments, to investigate the effect of high-altitude flying; 2) Freezing experiments, conducted primarily for the German air force to investigate treatments for persons who had been severely chilled, using prisoners at the Dachau camp; 3) Malaria experiments to test immunization for and treatment of malaria; 4) Mustard gas experiments to investigate treatment of injuries caused by mustard gas; 5 ) Sulfanilamide experiments to test the effectiveness of sulfanilamide and other drugs as treatments for infected wounds;6) Bone, muscle, and nerve regeneration, and bone transplant experiments; 7) Seawater experiments to test methods of making seawater drinkable; 8) Epidemic jaundice experiments to investigate causes of and inoculations against epidemic jaundice; 9) Typhus ("spotted fever") and other vaccine experiments to test the effectiveness of vaccines against typhus, smallpox, cholera, and other diseases; 10) Poison experiments to investigate the effect of various poisons, including poison in food and poisoned bullets; 11) Sterilization experiments to develop methods of rapid, large scale sterilization in order to ensure the eventual elimination of "enemy" populations while keeping captive workers as a labor force during the war; 12) Skeleton collection for an anatomical research project at the Reich University of Strasbourg, 112 Jews at Auschwitz were killed for the purpose; 13) Phenol (gas oedema) experiments to investigate whether levels of phenol in gas oedema serum caused fatalities among wounded soldiers; and 14) Polygal experiments to test the effectiveness of polygal, a blood coagulant, for the treatment of wounds.

117 In one example, PHR admits the evidence available to it does "not demonstrate that the experimental regime employed on detainees came complete with stated hypotheses, methodology, results, and conclusions-the fundamental elements of all legitimate scientific investigation." PHR, EXPERIMENTS IN TORTURE, supra note 113, at 7. 
knowledge rather than therapy."118 This focus on purpose is not to suggest that ends testing appropriately distinguishes the Nazi doctors from United States health providers-what the Nazi doctors were actually doing is also dramatically different from what United States HPs were doing-but rather to demonstrate that what United States HPs were doing simply did not constitute medical experiments.

\section{a. Law}

Like general and specific planning discussed above, no specific law prohibits HPs from participating in intrainterrogation consultation, meaning criminal legal liability for intra-interrogation consultation would rely on theories of secondary liability. The possibility of accomplice liability seems high, assuming the activities recommended by the MHPs constituted violations of law, as the direct, real-time provision of advice to employ a particular technique would certainly meet the required mens rea and actus reus elements of accomplice liability.

To the extent that HP involvement in intra-interrogation consulting converted the interrogations to medical experiments-a contention that seems plainly wrongconducting non-consensual "medical experiments" on detainees would be, without question or equivocation, a

118 M. Cheriff Bassiouni, An Appraisal of Human Experimentation in International law and Practice: the Need for International Regulation of Human Experimentation, 72 J. CRIM. L. \& CRIMINOLOGY 1597, 1597 (1981) (emphasis added). Introduction to NMT Case 1: U.S.A. V. Karl Brandt et al., Nuremberg Trials Project: A Digital Document Collection, HARV. L. SCH. LIBR., http://nuremberg.law.harvard.edu/php/docs_swi. php?DI=1\&text=medical\#indictments (last visited Dec. 23, 2013). Similarly, Professor George Annas, a distinguished bioethicist and legal scholar-and no apologist for enhanced interrogation techniques or HPs' assistance in them -acknowledged the activities PHR alleges constitute "experiments" or "research" do not actually constitute research, in part because the activities "do not follow the National Institutes of Health definition of research, which includes having a hypothesis and at least a historical control group." Lewis, supra note 19 (emphasis added). Annas also observes the debate over experimentation is a red herring, saying, "[I]t misses the point to call it research. It's torture and there's no reason to dignify it as research." Id. 
violation of numerous international and domestic laws, including several of the Geneva Conventions and the WCA. ${ }^{119}$ Perhaps it is these clear legal prohibitions that entice some commentators to make the as-yet unsupported claim that United States HPs conducted medical experiments. While some of the shameful interrogation techniques employed by the United States may have been

119 See, e.g., Geneva I, supra note 15, at art. 50; Geneva III, supra note 15 , at arts. $13,14,130$; Geneva IV, supra note 15 , at arts. 32,147 ; ICCPR, supra note 48 , at art. 7; 18 U.S.C. $\S 2441(\mathrm{~d})(1)(\mathrm{C})$. As noted above, the amended WCA also bans biological experiments on detainees, but unlike Geneva III's prohibition, does so only if the experiment "endangers the body or health of such person or persons." Thus, it is theoretically possible "experiments" could violate Geneva but not the WCA if they did not endanger the subject of the experiment.

Moreover, several international ethical norms likely have attained the status of customary international law. See, e.g., Nuremberg Code, supra note 17; Declaration of Helsinki, supra note 27; see also Jennifer Seo, Raising The Standard Of Abortion Informed Consent: Lessons To Be Learned From The Ethical And Legal Requirements For Consent To Medical Experimentation, 21 COLUM. J. GENDER \& L. 357, 375 (2011).

Additionally, a United States federal statute codifies the prohibition of conducting human experiments on non-consenting subjects, though it enforces that prohibition through withholding of funds not applicable to the activities addressed in this paper. See 42 U.S.C. $\S 3515$ b (2013) (prohibiting funds appropriated to the Departments of Labor, Health and Human Services, Education, or related agencies from being used on research programs involving experiments with non-consenting human subjects). A policy regulation issued by the Department of Health and Human Services, also prohibits experiments without the subject's consent. See 45 C.F.R. $\S \S 46.101 * 119$ (2013) (requiring informed consent before conducting experiments on human subjects except in very limited circumstances not applicable here). This regulation was adopted by DoD. See DoDD 3216.2, supra note 25. Additionally, numerous executive orders have specifically prohibited the practice of engaging in human experiments by United States intelligence agencies. See, e.g., Exec. Order No. 12,333 $§ 2.10,46$ Fed. Reg. 59941 (Dec. 4, 1982) (requiring written informed consent for any human experimentation by an agency within the Intelligence Community). Of note, at least one intelligence-related experiment program that would run afoul of several laws has become known. See Daniel L. Pines, The Central Intelligence Agency's "Family Jewels": Legal Then? Legal Now?, 84 IND. L.J. 637, 645 -646 (2009). This program involved administration of LSD and other drugs to United States citizens without their knowledge and consent for the purpose of building a defense to feared Soviet drug-based attacks. Id. 
illegal, they simply did not constitute medical experiments. Such unjustified shoehorning leads to the problem, the consequences of which are discussed below, of suggesting that the law prohibits certain behaviors when it does not.

\section{b. Ethics}

International and domestic ethical standards that prohibit facilitating interrogation such that involvement in specific interrogation planning is disallowed obviously also prohibit intra-interrogation consultation. As noted above, in 2006, the WMA, AMA, and American Psychiatric Association prohibited facilitating specific interrogation. The AMA specifically insists physicians not "directly participate" in interrogation, though it fails to define "directly," leaving some question as to whether providing stand-off consultation to interrogators would be permissible. ${ }^{120}$ The American Psychiatric Association also prohibits "direct participation" in interrogation, defining it as "being present in the interrogation room, asking or suggesting questions, or advising authorities on the use of specific techniques of interrogation with particular detainees." Clearly all forms of contemplated intrainterrogation consultation would constitute "direct participation" under this standard.

By contrast, psychologists are not completely prohibited from participating in interrogations, including intrainterrogation consulting. The APA only prohibits involvement in interrogation involving torture or cruel, inhuman, or degrading treatment or working in settings where persons are "held outside of or in violation of international law or the United States Constitution."121 In fact, the 2006 APA Resolution Against Torture provision

120 AMA Opinion 2.068, supra note 29, para. 2. AMA Opinion 2.068 does include an apparently non-exclusive example of "direct participation": monitoring interrogations "with the intention of intervening in the process." Id. at para. 3.

1212006 APA Resolution Against Torture, supra note 32; 2008 APA Resolution Against Torture, supra note 33; APA Resolution on Detainee Settings, supra note 88 . 
that requires psychologists, "if present when torture or cruel, inhuman, or degrading treatment occurs to try to stop the abuse or exit the procedure"; this suggests psychologists might be present at interrogations. ${ }^{122}$ Thus, whether a psychologist may ethically engage in intra-interrogation consulting depends on the actions of the interrogators. Again, were HPs' conduct to be considered non-consensual medical experimentation, a variety of ethical standards clearly prohibit nonconsensual experimentation. ${ }^{123}$

\section{Examples: Health Evaluations and Interrogation Monitoring}

MHPs have regularly conducted examinations of detainees before and after interrogation and monitored detainee health during some interrogations. These activities are distinguished from general medical and mental treatment discussed below because the alleged purpose of the examinations and monitoring is to determine the suitability for initiating, continuing, or resuming interrogation.

In fact, as described above, DoD policy required medical screening before detainees could be subjected to several of the interrogation methods approved by Secretary Rumsfeld, including waterboarding, solitary confinement, sleep deprivation, stress positions, and dietary manipulation, and in some cases required monitoring during the use of the techniques. ${ }^{124}$

Examples of pre- and post-interrogation health assessments are available from multiple theaters of operations. For example, according to the interrogation logs, military physicians frequently monitored Qahtani's physical condition during the weeks of interrogation,

1222006 APA Resolution Against Torture, supra note 32.

123 See, e.g., Nuremberg Code, supra note 17; Declaration of Helsinki, supra note 27.

124 See, e.g., Rumsfeld Approval Memorandum of April 2003, supra note 10 . 
"sometimes as often as three times a day. . . ."125 In Iraq, one Air Force medical team reported examining "each Abu Ghraib detainee before and after interrogation."126 In fact, the Air Force team, which consisted of one physician, one physician's assistant, and two medics, "provided initial medical assessments of detainees to determine preexisting conditions that might affect the interrogation process; it was also tasked with completing pre-, trans-, and postinterrogation medical assessments on an individual basis, at the request of the interrogators." 127

In addition to pre- and post-interrogation assessments, some HPs have been involved in assessments or monitoring during the use of interrogation techniques. For example, interrogated detainees in Iraq were monitored by Air Force doctors during use of the sleep deprivation technique. ${ }^{128}$ Additionally, detainees alleged "HPs examined their condition during an episode of torture or physical abuse but, as far as the detainees could tell, made no effort to stop it." 129

Finding details of how frequently HPs have been involved in monitoring is difficult, though the 2005 Army Surgeon General's Assessment clearly demonstrates HPs were periodically present during questioning of detainees. Of sixty-six interviewed MHPs who had served in Afghanistan, seven had been physically present during an interrogation, though none had "participated" in an interrogation. ${ }^{130}$ Of the nine interviewed MHPs who had served at Guantanamo, none reported having been present during interrogation. ${ }^{131}$ Finally, in Iraq, 39 of 777 interviewed MHPs had been present during at least one

125 Adam Zagorin \& Michael Duffy, Inside the Interrogation of Detainee 063, TIME, June 20, 2005, at 26, 27.

126 MiLES, supra note 3 , at 51.

127 Army Surgeon General Assessment, supra note 55, at 11-2.

128 Sworn statement of [name redacted], 519TH MILITARY INTELLIGENCE BATTALION 5 (May 19, 2004) (noting the purpose of the monitoring was to ensure detainees were not harmed), available at http://www.aclu.org/files/projects/foiasearch/pdf/DOD000867.pdf.

129 Hashemian, et al., supra note 6, at 86.

130 Army Surgeon General Assessment, supra note 55, at 18-18.

131 Id. at $18-19$. 
interrogation. ${ }^{132}$ Five had participated in the interrogation, with two serving as translators, two medics directly asking questions of detainees (because of Arabic fluency or rapport with detainees), and one physician reported feigning evaluations and treatment on detainees by pretending to do DNA tests from a hair sample and a buccal swab. ${ }^{133}$

\section{a. Law}

As with many of the activities discussed in this article, no law specifically prohibits HPs from conducting medical or mental health evaluations before, during, or after interrogation, meaning whether such evaluations would violate law depends entirely on secondary liability theories.

In addition to the lack of legal proscription, the legality of medical monitoring or evaluations before, during, or after interrogation sessions is complicated by the fact that some law requires medical evaluation and treatment of detainees. For example, Geneva III, article 15, requires the detaining power to provide to prisoners of war the "medical attention required by their state of health." Though it may seem specious to argue medical exams are required by detainees' poor state of health when the detaining power is responsible for creating that state of health, no derogation from Article 15 's requirement is provided. Surely, if an interrogator-or even a prison guard in a non-interrogation settingcommits a plainly illegal battery on a detainee, medical evaluation must be conducted, whether or not that evaluation is followed by further interrogation.

\section{b. Ethics}

As noted previously, the revised Declaration of Tokyo now explicitly forbids physicians to use their knowledge to facilitate any interrogation, raising the significant question of whether conducting a medical examination or monitoring "facilitates" the interrogation. ${ }^{134}$ Moreover, the WMA

132 Id. at $18-21$.

133 Id. at $18-21$ through -22 .

134 Revised Declaration of Tokyo, supra note 27. 
Regulations in Times of Armed Conflict explicitly states it is unethical for a physician to perform diagnostic procedures "not justifiable for the patient's health care," suggesting that evaluations to determine whether an individual could withstand further interrogation-and not for the purpose of improving that patient's physical condition-are impermissible. ${ }^{135}$

Domestic ethical standards are less clear regarding evaluations and monitoring interrogation. ${ }^{136}$ For example, the AMA allows physicians to perform physical and mental assessments of detainees to determine the need for and provide medical care, as long as they "disclose to the detainee the extent to which others have access to information included in medical records." Therefore, under the AMA's standards, conducting medical and mental health evaluations is permissible so long as it is to determine the need for medical care. This raises the question of dual purposes. If the physician is conducting the evaluation both genuinely to determine the detainee's need for medical care and to give a clean bill of health that allows interrogation to continue, has the AMA position been violated? Neither the American Psychiatric Association nor the APA has specifically addressed medical monitoring or mental health evaluations.

As in other areas, evaluations and monitoring pose difficult questions regarding secondary liability for HPs. One of the purposes for having HPs monitor interrogations is to determine whether the implementation of a technique crosses the threshold of severity ("severe physical or mental pain") that would make it a violation of law. If the health

135 WMA Regulations in Times of Armed Conflict, supra note 27.

136 This "nuance" applies only to the more generalized question of monitoring for interrogation. The AMA's position regarding monitoring torture is crystal clear. AMA's Opinion 2.067, entitled "Torture," enacted in December 1999 and, thus, applicable throughout the GWOT, provides that physicians may treat detainees if doing so is in the best interest of the detainees' health, "but physicians should not treat individuals to verify their health so that torture can begin or continue." Thus, here, as elsewhere, whether a physician's medical assessments constitute a violation of medical ethics depends upon whether the underlying activity constitutes torture. 
professional incorrectly finds the technique will not cause severe physical or mental, has she or he aided or abetted commission of crime? More basically, if medical monitoring is required by policy, does not the provision of that monitoring "facilitate" the interrogation? Indeed, one could argue it is legally necessary for the interrogation to continue. If the health professional's opinion is that the detainee is capable of withstanding further interrogation, it seems liability would depend on whether the subsequent interrogation was illegal, something over which the health professional is unlikely to have control.

\section{General Medical Care}

Article 15 of Geneva III requires detaining powers to provide to prisoners of war "medical attention required by their state of health."137 In the GWOT, detainee healthcare has been provided by MHPs who are generally unassociated with interrogation operations. However, even this purportedly distinct provision of care has given rise to allegations of involvement in interrogation and torture.

For much of the GWOT, the Department of Defense has established a separation between HPs involved in interrogation and intelligence collection activities and those responsible for the general medical and mental welfare of the detainee population. Indeed, in its final regulatory codification of this dichotomous vision, perhaps in an implicit acknowledgment of professional ethical standards, DoD provided: "Health care personnel engaged in a professional provider-patient treatment relationship with detainees shall not participate in detainee-related activities for purposes other than health care. Such health care personnel shall not actively solicit information from detainees for other than health care purposes."138

However, as noted above, even HPs who were separately responsible for general medical care at the detention facility, and were not involved in "detainee-related activities for purposes other than health care" (i.e., interrogation), are

137 Geneva III, supra note 15.

138

DoDI 2310.08E, supra note 2. 
alleged to have "enabled torture" for failing to notice or report injuries indicative of abuse, deliberately concealing abuse, withholding care to obtain information, providing medical or mental health care for the purpose of furthering interrogation, forced feedings of detainees, and sharing confidential medical information with interrogators. Indeed, one critic has alleged HPs became enablers of torture merely by "providing medical care in an environment where torture was taking place."139

\section{Examples: Failure to Identify or Report Evidence of Interrogation-Related Abuse}

Health personnel have been criticized for failing to notice and report interrogation-related injuries, allowing abusive interrogations to continue. ${ }^{140}$ However, specific instances of HPs otherwise unassociated with interrogation failing to identify or report evidence of interrogation-related abuses are difficult to find. Though there are some vaguely reported instances of HPs failing to notice or report instances of physical or psychological harm detainees suffered, it is not clear whether those abuses were interrogation-related. ${ }^{141}$

139 Hashemian et al., supra note 6, at 85-86.

140 This suggests such personnel could distinguish between interrogation-related abuses and non-interrogation-related abuses, which seems unlikely. For example, abuses of detainees at Abu Ghraib have been well documented, but not all abuses of detainees are interrogation-related. Christopher Graveline \& Michael Clemens, THE SECRETS OF ABU GHRAIB REVEALED 299 (2010) (observing that "the vast majority, and most notorious, photographs of abuse [at Abu Ghraib] had nothing to do with intelligence collection. Many of the victims, plain and simple, were not terrorists or even interrogated"). This book, authored by individuals involved in the investigation and prosecution of United States military personnel involved in the atrocities at $\mathrm{Abu}$ Ghraib, offers an extraordinarily intimate and seemingly objective view of the Abu Ghraib nightmare and subsequent response. See also Army Surgeon General Assessment, supra note 55, at 14-2 (noting injuries can be due to lawful combat operations and lawful physical force required to maintain discipline in a detention facility).

141 The Church Review cites one such example, where detainees died and physicians found "no evidence of bruising or injury" but autopsies days later "revealed massive blunt force injuries to the legs, 
That physical abuses have occurred in the course of interrogations of detainees is clear. ${ }^{142}$ It is reasonable to assume some of these detainees were taken to detention facility medical units to obtain medical care. However, there are a host of legitimate reasons why health professional might not report suspicious injuries as evidence of interrogation-related abuses. First, it is not at all clear HPs can distinguish between interrogation-related and noninterrogation-related injuries (that may have been selfinflicted, caused by other detainees, or caused before the individual was even detained). Second, the health professional might not recognize the injury as suspicious. ${ }^{143}$ Finally, the patient may request that the injury not be reported. None of these situations excuse HPs from reporting if they actually believe the injuries were caused by abusive interrogation, but they do explain why some injuries may not have led to a report.

Further, it may be difficult for HPs to demonstrate when they did champion a detainee's health, only to be dismissed by interrogators. ${ }^{144}$ Further, it is entirely possible

with muscle injury so severe that bilateral leg amputations would have been necessary if the detainee had survived." CHURCH REVIEW, supra note 111, at 363. The Church Review continued, "Review of these cases with [the medical examiner] support our concern that local physicians may have misrepresented, either consciously or due to incomplete examinations the condition of these detainees at death." Id.

The distinction between abusive interrogation and other abuses (such as by personnel capturing the detainees or by detention facility guards) is relevant to this article, because it is about interrogationrelated activities. The distinction is likely irrelevant under the law or ethical guidelines mandating reporting.

142 The SMUTF-Iraq legal advisor told a visiting assessment team from Guantanamo about physical violence being used by SMUTF personnel during interrogations, including punching, choking, and beating detainees. SASC REPORT, supra note 44, at 193.

143 "Failure to report" may involve a predicate concern: the failure to identify evidence of torture. Moreover, allegations of failure to identify raise the question of whether the failure was negligent or intentional.

144 In one such instance, a psychology technician at GTMO complained to the cell block officer-in-charge about the officer's refusal to allow a detainee to be seen by medical personnel for back pain, to which the officer-in-charge purportedly replied: 
interrogation-related abuses regularly were reported by HPs and that such reports, like so many other facts in this area, remain classified.

According to the commander of the medical unit that staffed Abu Ghraib during the time of the abuses made notorious by soldiers' photographs, "military intelligence personnel told his medics and physician assistants not to discuss deaths that occurred in detention." 145 In one instance, two physicians at $\mathrm{Abu}$ Ghraib allegedly "recognized that a detainee's shoulder was hurt because he had his arms handcuffed over his head for what they said was 'a long period." 146 The two physicians provided palliative care, then sent the detainee to a non-United States hospital, and did not report any suspicions of abuse. ${ }^{147}$

Physical injuries are not the only types of injuries reportedly ignored by HPs; mental health injuries also allegedly escaped notice and reporting. PHR alleges HPs at Guantanamo "provided pharmacological treatment for suicidal, self-destructive, and partly psychotic behavior that is at least partially attributable to the torture-including isolation-the detainees experienced, yet the health providers only marginally intervened to stop his torture."148 Further, according to PHR, by identifying "routine stressors of confinement," as causes for the detainee's mental health problems, the involved psychiatrists "disregarded cruel or ill-treatment as a likely cause of these symptoms." 149

Listen, bitch, I run this cellblock the way I see fit. If I think a detainee is complaining about back pain just to get to walk across the camp to the medical clinic one sunny afternoon, then I'm not going to put it in my log. Now leave my block and next time stay in your lane.

ERIK SAAR \& VICECA NOVAK, INSIDE THE WIRE 73-74 (2005).

145 M.G. Bloche \& J.H. Marks, Doctors Go To War, supra note 10, at 4.

146 Kate Zernike, The Reach of War: The Witnesses; Only a Few Spoke Up on Abuse As Many Soldiers Stayed Silent, N.Y. TIMES, May 22,2004 , at $\mathrm{Al}$.

147 Id.

148 Hashemian et al., supra note 6, at 86.

149 Id. 
Relying on these facts, PHR concluded that "[i]n sum, the HPs were complicit in the torture of this detainee."150

In contrast to the assertions of non-reporting by commentators, the Army Surgeon General's Assessment conducted in 2005 asked HPs who had served or were serving in Iraq, Afghanistan, and at Guantanamo about their reporting of suspected abuses. Of 798 interviewed MHPs who had served at detention facilities in Afghanistan, Guantanamo, and Iraq, forty-three indicated detainees had reported abuse to them, and the health professional had reported all but four instances of alleged abuse. ${ }^{151}$ Of the four who indicated they did not report the abuse, three were because the health professional thought the claim lacked credibility and one believed he or she lacked sufficient information. ${ }^{152}$ Five hundred ninety-six MHPs who had served at detention facilities in Afghanistan, Guantanamo, and Iraq were asked whether they personally observed signs of possible abuse. ${ }^{153}$ Thirty indicated they had; 25 reported that abuse. ${ }^{154}$ Of the five unreported cases, the Army Surgeon General's Assessment indicated three were because action was otherwise taken. ${ }^{155}$

\section{a. Law}

A legal duty to report various abuses is not strange to HPs, who operate under state laws requiring reporting in various circumstances. ${ }^{156}$ However, at the inception of the

150 Id.
151 Army Surgeon General Assessment, supra note 55, at 16-1 n.2.
152 Id. at n.3.
153 Id. at $\mathrm{n} .2$.
154 Id. at $\mathrm{n} .3$.
155 Id. The other two were unexplained.
156 An interesting corollary is the many state statutes, rigorousl adhered to by MHPs in the United States, that mandate reporting when HPs suspect child or spousal abuse. For example, the United States Department of Health and Human Services reports forty-eight states have laws mandating medical professionals report child maltreatment. Child Welfare Information Gateway, Mandatory Reporters of Child Abuse and Neglect: Summary of State Laws (Apr. 2010), available at http://www.childwelfare.gov/systemwide/laws_policies/statutes/manda.cf 
GWOT, no clear law required reporting interrogationrelated abuses. ${ }^{157}$ Contrary to popular perception, service members do not have a general duty to report any violation of which they are aware. Rather, the duty must be specifically imposed. ${ }^{158}$ Additionally, such a duty would not arise where mandatory reporting would violate the service member's rights against self-incrimination (for example, if the service member were an accomplice to the alleged crime). 159 Further, after the approval of various harsh interrogation techniques by the Bush Administration, involved service members understandably might have assumed no duty to report was implicated when detainees sustained physical or mental injuries that purportedly resulted from authorized interrogation procedures.

Fortunately, whatever ambiguity might have existed at the beginning of the GWOT regarding the duty to report suspected abuse was eventually resolved. DoDI 2310.08E, paragraph 4.5, imposed a clear burden on MHPs to report any observed or suspected violations of United States law to the chain of command. Further, it prescribed alternative reporting avenues if the health professional believed the chain of command was not acting properly on the report. Thus, after the promulgation of DoDI 2310.08E in 2006, and so long as it remains in effect, there should be no question regarding the duty to report suspected abusive interrogation.

m. By contrast, no such statutory requirement, at the state or federal level, to report suspected torture is imposed on HPs as a profession.

157 Army Medical Command legal guidance apparently, imposed a reporting requirement, but not until well after alleged interrogation abuses began. See Army Surgeon General Assessment, supra note 55, at 15-2, 16-2 (citing Health Care Professional Detainee Abuse Reporting Requirements (Sept. 8, 2004)).

158 See United States v. Heyward, 22 M.J. 35, 36 (C.M.A. 1986) (stating a duty to report must be specifically imposed and noting the offenses of being an accessory after the fact and misprision of a felony require affirmative acts of concealment or assistance in addition to failure to report).

159 See Kastigar v. United States, 406 U.S. 441, 445 (1972). 


\section{b. Ethics}

While physicians, including psychiatrists, and psychologists have a duty to report ethical violations of fellow professionals, like the law, professional associations were late in clarifying the duty to report as it applied to suspected interrogation-related abuses. AMA Opinion 2.068, promulgated in 2006, stated physicians must report "coercive interrogations" to appropriate authorities and if such authorities are aware of such interrogations but have not intervened, they must report the offenses to other authorities with the power to investigate or adjudicate the allegations. The American Psychiatric Association, on the other hand, only requires psychiatrists to report when they become aware "torture" has occurred. The APA imposes no specific duty to report specific to torture or interrogation. Application of these ethical standards is difficult because whether particular abuses were caused by interrogation or torture-thus implicating the ethics rules-would be difficult to ascertain.

\section{Examples: Concealing Interrogation-Related Injuries}

Going a step beyond the omissions of failing to identify and report interrogation-related abuse, some have asserted HPs were engaged in affirmative efforts to conceal detainee abuse. Publicly available evidence of this alleged practice is virtually non-existent. One notorious, although only partially relevant, incident involved concealing the death of a detainee ostensibly caused by injuries. ${ }^{160}$ After capturing Manadel Al-Jamadi, Navy SEALs allegedly beat and kicked him prior to turning him over to CIA personnel for interrogation at Abu-Ghraib. ${ }^{161}$ After several hours of interrogation, Mr. Jamadi died and his body was packed in

160 This instance of alleged concealment did not relate to interrogation-related detainee abuse, but is included to demonstrate the type of activity one might argue constituted deliberate concealment by medical personnel.

161 David S. Cloud, Seal Officer's Trial Gives Glimpse of C.I.A. Role in Abuse Scandal, N.Y. TIMES, May 26, 2005, at A13. 
ice. Before leaving the facility, a medic inserted an IV in Mr. Jamadi's corpse and the body was rolled out of the facility on a medical gurney. The intent of the medical personnel is unclear. While Vice Admiral Church's investigation found that "medical personnel may have attempted to misrepresent the circumstances of death, possibly in an effort to disguise detainee abuse," the subsequent Army Surgeon General's investigation of the matter accepted the explanation of the commander overseeing the interrogation that the ruse was to avoid upsetting other detainees. ${ }^{162}$

\section{a. Law}

Though there are no laws specifically addressing such concealment in the context of interrogation, let alone specifically prohibiting medical providers from engaging in such subterfuge, deliberate concealment of illegal activity by service members is itself illegal. ${ }^{163}$ However, while there may be evidence that possibly suggests some HPs failed to take appropriate action in response to apparent interrogation-related abuse, there simply is no publicly available evidence that MHPs engaged in deliberate concealment.

\section{b. Ethics}

As with the law, though there are no specific ethics provisions that prohibit concealing illegal forms of interrogation, concealment clearly constitutes facilitation. Thus, the various ethical standards discussed above that

162 Army Surgeon General Assessment, supra note 55, at 20-5; CHURCH REVIEW, supra note 111, at 21; see also MILES, supra note 3 , at 45 (asserting the Armed Forces Institute of Pathology's failure to provide the results of the autopsy and the death certificate to the ICRC or Mr. Jamadi's family constituted further concealment of the homicide).

163 See, e.g., 10 U.S.C. $\$ \S 878,934$ (2013) (criminalizing acts of concealment by accessory after the fact and criminalizing "misprision of a serious offense"). 
prohibit facilitation of interrogation or torture would clearly prohibit concealment of the same. ${ }^{164}$

\section{Examples: Withholding Care To Obtain Cooperation}

Another situation in which "general medical care" has been alleged to constitute actual involvement in interrogation is when medical care is withheld until the individual being interrogated cooperates and provides information. Allegations to this effect have generally ignored the critical (for purposes of this article) fact that health professionals were not the individuals denying or withholding the care. ${ }^{165}$ Actual evidence of HPs withholding medical care from detainees for noncooperation is exceedingly difficult to find.

The idea that medical care could be withheld to further interrogation purposes was directly acknowledged by the most senior DoD official when, in December 2002, Secretary Rumsfeld authorized, as a "Category II" interrogation technique, isolation of individual detainees, during which "medical visits of a non-emergent nature" were within the discretion of the officer-in-charge of interrogation. ${ }^{166}$ Withholding medical or mental health care to obtain cooperation in interrogation is clearly a violation of law. Common Article 3 demands "the wounded and sick shall be cared for." Geneva III requires the detaining power to provide to prisoners of war "medical attention required by their state of health," 167 states that "[p]risoners of war may not be prevented from presenting themselves to the medical

164 See, e.g., WMA Regulations in Times of Armed Conflict, supra note 27, para. 2(e); Revised Declaration of Tokyo, supra note 27; AMA Opinion 2.068, supra note 29.

165 See, e.g., Hashemian et al., supra note 6, at 85.

166 Memorandum from William J. Haynes II, Gen. Counsel for Department of Defense, to Donald Rumsfeld, Secretary of Defense, Counter-Resistance Techniques (Nov. 27, 2002) [hereinafter Rumsfeld Approval Memo of Nov. 2002], available at http://www.dod.mil/pubs/foi/ operation_and_plans/Detainee/additional_detainee_documents/07-F$2406 \% 20$ doc\%201.pdf.

167 Geneva III, supra note 15, art. 15. 
authorities for examination," 168 and prohibits subjecting POWs to "disadvantageous treatment of any kind" for failure to answer questions, ${ }^{169}$ and it prohibits endangering the health of a POW.170 Clearly, Secretary Rumsfeld's 2002 decision that Guantanamo interrogators could disapprove a detainee's "medical visits of a non-emergent nature" violated these provisions (to the extent they applied).171 Nothing in the cited provisions of the Geneva Conventions limits a detaining power's responsibility to provide medical care to detainees only in emergency situations.

Though some critics allege HPs were directly involved in the withholding of care in exchange for information, it seems more likely that access to HPs would be withheld by interrogators, rather than HPs interacting with sick or injured detainees and choosing not to treat them. ${ }^{172}$ In fact, no specific cases of health professionals withholding care for the purpose of obtaining cooperation in interrogation have been reported. Indeed, Secretary Rumsfeld's memorandum suggests the interrogation team, not HPs, would determine whether detainees would get such access to non-emergent care.

Though this article focuses on MHPs and military detention and interrogation, it is illustrative in this context to note the CIA considered the act of withholding pain

$\begin{array}{ll}168 & I d . \text { at art. } 30 . \\ 169 & \text { Id. at art. } 17 . \\ 170 & \text { Id. at art. } 13 .\end{array}$

171 Rumsfeld Approval Memo of Nov. 2002, supra note 166. Of course, Guantanamo detainees were determined not to be entitled to the protections of Geneva III. However, applying that decision in cases where Geneva III might have applied, such as in Iraq, would clearly have been contrary to Geneva III.

172 See, e.g., Brewer \& Arrigo, supra note 7, at 8 (reporting a specific example where a non-cooperative detainee was offered pills to cure their dysentery, but only if they provided information, and arguing "commanders may simply order medical personnel to place their loyalty to country above their medical care for a detainee, including by trading medical treatment for information during interrogations"); Hashemian et al., supra note 6 , at 85 (noting that a detainee complained of being denied medical care "due to a perception that he was not cooperating with officials" and he had to ask to see a doctor more than ten times before he was referred for care). 
medication until a detainee cooperated to constitute an "enhanced interrogation technique." ${ }^{173}$ At least one instance of CIA use of this method has been documented. After Abu Zubaydah was shot in the groin during his capture, "painkillers were used selectively in the beginning of his captivity until he agreed to cooperate more fully" with interrogators. ${ }^{174}$ Even in this instance, it is difficult to discern whether medical personnel were involved in the withholding of painkillers, though the fact he was receiving some medical treatment at the time suggests it is at least possible medical personnel were, at a minimum, aware pain relieving medication was being withheld. ${ }^{175}$

Though unclear which agency was responsible, another detainee reported he was denied medical care for a gunshot wound in his shoulder because he refused to cooperate with interrogators while he was "tortured" for three days after capture in Afghanistan, with interrogators implying he could receive treatment after cooperating. ${ }^{176}$ Other cases of denied or delayed medical care pending detainee cooperation with medical care include denial of antibiotics for festering wounds and treatment for constipation. 177

Perhaps because the practice is so clearly prohibited by law and ethical standards, virtually no evidence has been produced that these allegations-medical and mental health providers withholding necessary care to obtain cooperation in interrogation-actually occurred in United States military detention facilities. As noted above, it is alleged that Abu Zubaydah received delayed care after being shot in the groin, but there is no evidence health professionals were involved in the delay.

173 Dana Priest, CLA Puts Harsh Tactics on Hold, WASH. Post (Jun. $27,2004)$, at $\mathrm{A} 01$.

174 Id.

175 MiLES, supra note 3 , at 61 (quoting Secretary Rumsfeld, referring to Abu Zubaydah, as saying, "He is receiving medical care and we intend to get every single thing out of him to try to prevent terrorist acts in the future.").

176 FBI Interview Memo (Sept. 5, 2002) (Bates-stamped DETAINEES-3894), http://www1.umn.edu/humanrts/OathBetrayed/ FBI\%203890-3927.pdf.

177 MILES, supra note 3, at 62. 
a. Law

If a service member or other person acting on behalf of the United States were to prevent POWs from presenting themselves for medical examination, that would constitute a breach of the United States' treaty obligations under Common Article 3 and Geneva III. However, it is important to note that, as a factual matter, it is unlikely health professionals - rather than individuals actually in control of detainees-would be preventing POWs from presenting themselves for medical examination. In the example recounted in note 143 above, it was the interrogators who denied access to medical care (telling the health professional to "stay in your lane"). This makes sense for several reasons: the detainees are under the physical control of the detention team or interrogation team, not the HPs; the detainees are physically separated from the HPs; and the HPs (other than the BSCT members, who do not provide treatment) typically would have no idea whether or not the detainee is being cooperative in interrogation.

\section{b. Ethics}

One professional association articulated an ethics standard expressly prohibiting conditioning treatment on a patient's participation in an interrogation. AMA Opinion 2.068 states that "[t]reatment must never be conditional on a patient's participation in an interrogation." 178 Additionally, if engaged in by $\mathrm{HPs}$, withholding medical care for the purpose of obtaining cooperation clearly would constitute "facilitation" of interrogation prohibited by various ethical standards, as discussed above. ${ }^{179}$

178 AMA Opinion 2.068, supra note 29.

179 See, e.g., id. at para. 2; Revised Declaration of Tokyo, supra note 27. 


\section{Examples: Providing Care for the Purpose of Furthering Interrogation}

Critics have accused United States MHPs of providing medical care for the primary or sole purpose of enabling further interrogation. The factual basis for such assertions remains elusive, in large part because even in the unusual circumstance where some information regarding a detainee's medical care is available, it is difficult to determine the intent in providing medical care to detainees suffering from the physical or mental effects of their detention and interrogation. For example, Qahtani became very ill at one point during his extended interrogation. ${ }^{180} \mathrm{~A}$ military physician reported Qahtani's heart rate dropped to thirty-five beats a minute, apparently due to hypothermia caused by intentionally extreme air conditioning. 181 Significant medical efforts were undertaken, including flying a radiologist to Guantanamo from Puerto Rico to review CT scans. ${ }^{182}$ Ultimately, the interrogation resumed. 183 Whether the involved HPs were simply fulfilling their duty to alleviate his suffering and improve health or, as critics assert, patch him up for the purpose of allowing interrogation to continue cannot be determined with available information.

The extraordinarily comprehensive investigation conducted at the direction of the Surgeon General of the Army in 2005 uncovered little evidence of providing medical care for the purpose of allowing interrogation to continue. Of 438 interviewed HPs who had served in Iraq, seven reported having been "asked to provide medical care to detainees during interrogations so that the interrogations could be continued," with each having done so only once. ${ }^{184}$

180 See Mayer, supra note 79 , at 68.

181 Zagorin \& Duffy, supra note 125 , at 32; MILES, supra note 3, at 61.

182 Zagorin \& Duffy, supra note 125 , at 32.

183 MiLES, supra note 3 , at 61.

184 Army Surgeon General Assessment, supra note 55, at 11-2. Interestingly, none of the Air Force team members involved in the interrogation screenings at $\mathrm{Abu}$ Ghraib were asked to provide medical care to detainees during interrogations so that the interrogations could 
Examples of the care delivered include providing food for hypoglycemia and intravenous fluid administration for symptoms of dehydration. 185 No interviewees who had served in Afghanistan or Guantanamo reported being asked to provide medical care during interrogations so that the interrogations could be continued or being aware of other medical personnel who were asked to do the same. ${ }^{186}$

Interrogation-caused injuries followed by medical care followed by further interrogation simply does not mean HPs were providing the medical care for the purpose of allowing interrogation to continue. Critics asserting HPs were providing health care for the purpose of allowing interrogations seem unfazed by these evidentiary gaps. One civilian psychiatrist who visited Guantanamo reviewed treatment logs and concluded the detainees were given "decent medical care," but she noted that this care was administered for the primary purpose of preparing individual detainees for additional harsh interrogations. ${ }^{187}$ She provided no detailed basis for that conclusion. In one specific instance involving a detainee at Guantanamo, who began showing severe symptoms of mental distress, mental health providers treated the detainee with psychotropic medication, but, according to PHR, "only intervened once, three months after his symptoms appeared" to alleviate isolation they believed worsened the detainee's condition. The detainee had been subjected to stress positions and isolation for several weeks and began exhibiting symptoms of severe mental distress including hallucinations, banging his head against a wall, and attempted suicide. ${ }^{188}$ Apparently on this evidence alone, PHR concluded the providers "became complicit in his torture, essentially

continue. They reported that "[i]f medical care was needed for detainees during an interrogation, the interrogation was stopped, treatment was rendered, and the interrogation did not continue." Id.

185 Id.

$186 I d$. at 11-1. The Assessment did not provide the total number of interviewees in Afghanistan and at Guantanamo who answered questions about providing medical care for the purpose of allowing interrogations to continue.

187 SANDS, supra note 101, at 161-68.

188 Hashemian et al., supra note 6, at 86 . 
patching him up in order for him to be subjected to further ill-treatment."189

\section{a. Law}

No law prohibits providing medical care for the purpose of furthering interrogation. When one considers the circumstances in which such an allegation could arise, this makes sense. Prohibiting medical care that allows further interrogation would mean medical care that is otherwise necessary would be disallowed. Ostensibly, for medical care to be "for the purpose of furthering/allowing further interrogation," the detainee's medical condition would be so dire the detainee could not withstand the contemplated interrogation technique without it. Under such circumstances, how could not. providing medical care be required by law?

There is little law governing the motivation or purpose for which medical or mental health care is provided to detainees. 190 Geneva III, Article 13's prohibition on endangering the health of a POW is the closest law on the issue, but raises as many questions as it answers. For example, some may argue that providing care to a detainee that allows the detainee to be returned to aggressive interrogation inherently endangers them. On the other hand, if a detainee needs medical care, regardless of the reason for that need, not providing the care endangers the detainee.

In any case where medical care is provided, at least a purpose of providing the care is because it is necessary for the detainee's health. No case has been presented where medical care has been provided to allow further interrogation and there has not also existed an independent need for medical treatment. Such a situation would necessarily entail elective medical care, and while the

189 Id. (emphasis added).

190 See supra Part III. As discussed above, Common Article 3 and Geneva III require that medical care be provided to detainees who need it. None of those provisions require any particular motivation, or lack of motivation, for providing the care. 
creativity of the wicked mind is limitless, it strains the imagination to envision elective medical care that would be necessary to allow further interrogation. Thus, even a case where a health professional is alleged to have provided care for the purpose of furthering interrogation will necessarily include an alternate legitimate purpose of providing care that is medically indicated.

\section{b. Ethics}

While some ethical standards flatly prohibit evaluations or monitoring for the purpose of allowing further interrogation to continue (for example, AMA Opinion 2.068's prohibition on certifying fitness of detainees for further interrogation), none prohibit providing healthcare that has the incidental effect of allowing interrogation to continue.

While concerns regarding the facilitation of interrogation-prohibited, as noted above, by several ethical standards-are likely raised when a health professional provides care that allows interrogation to begin or continue, when the care has an independent, legitimate, and perhaps ethically compelled purpose (alleviating the patient's suffering), it is difficult to understand how it could nevertheless be unethical to provide the care. Moreover, the AMA's position that physicians may perform physical and mental assessments of individuals undergoing interrogation "to determine the need for and to provide medical care," demonstrates at least the AMA believes providing care to detainees being interrogated is appropriate.

\section{Examples: Forced Feeding}

In an area related to providing care for the purpose of allowing interrogation to continue, forced feeding of detainees by MHPs has drawn significant criticism. ${ }^{191}$

191 See, e.g., George Annas, Hunger Strikes at GuantanamoMedical Ethics and Human Rights in a "Legal Black Hole," 355 NEW ENG. J. MED. 1377 (2006); Scott A. Allen \& Hernan Reyes, Clinical and Operational Issues in the Medical Management of Hunger Strikes, in INTERROGATIONS, FORCED FEEDINGS, AND THE ROLE OF HEALTH 
Forced feeding has been the subject of articles and books, and this article cannot address all the issues associated with MHPs force-feeding detainees. However, some discussion is appropriate, because this is an area where ethical standards, as pronounced by professional associations, have clearly addressed an issue the law has not.

Forced feeding of detainees at Guantanamo clearly occurred. ${ }^{192}$ Indeed, the details of the forced feedings at Guantanamo, which used restraint chairs, can be shocking. One detainee made this report:

The head is immobilized by a strap so it can't be moved, their hands are cuffed to the chair and the legs are shackled. They ask, 'Are you going to eat or not?' and if not, they insert the tube. People have been urinating and defecating on themselves in these feedings and vomiting and bleeding. They ask to be allowed to go to the bathroom, but they will not let them go. They have sometimes put diapers on them. 193

Professionals 201 (Ryan Goodman \& Mindy Jane Roseman eds., 2009); Hernan Reyes, Medical and Ethical Aspects of Hunger Strikes in Custody and the Issue of Torture, INTERNATIONAL COMMTTTEE OF THE RED CROSS (1998).

192 See, e.g., Eric Schmitt \& Tim Golden, Force-Feeding at Guantánamo Is Now Acknowledged, N.Y. TIMES (Feb. 22, 2006); Dr. William Winkenwerder, Assistant Secretary of Defense for Health Affairs, Media Roundtable with Assistant Secretary Winkenwerder, U.S. DEP'T OF DEF. (June 7, 2006), available at http://www.defense.gov/Transcripts/Transcript.aspx?TranscriptID=33 [hereinafter Winkenwerder, Media Roundtable] (acknowledging forced feeding is "a medical recommendation from a physician, and it's a command decision"); George Annas, Hunger Strikes at GuantanamoMedical Ethics and Human Rights in a "Legal Black Hole," 355 NEW ENG. J. MED. 1377 (2006); and Allen \& Reyes, supra note 191, at 201; Reyes, supra note 191.

193 See, e.g., Eric Schmitt and Tim Golden, Force-Feeding at Guantánamo is Now Acknowledged, N.Y. TIMES (Feb. 22, 2006) (quoting detainee Emad Hassan). 
While the broader question of the propriety of forced feeding is important, of relevance to this article is whether forced feeding is administered for the purpose of furthering interrogation. As with the medical care discussed in the immediately preceding section, the motivation behind forced feeding is unclear. DoD officials generally have argued forced feeding at Guantanamo was premised on respect for "life."194 Perhaps more candid assessment would reveal the Pentagon's concern for the international public relations difficulties posed by dying detainees. However, little evidence has been produced demonstrating detainees have been force fed so they could undergo interrogation.

\section{a. Law}

International law is generally silent on forced feeding of prisoners. Domestically, courts have generally permitted forced feeding where the forced feeding is performed by a physician in accordance with good and accepted medical procedures and the prisoner is either suicidal or the treatment refusal presents a considerable security problem for the entire prison. ${ }^{195}$ This reflects a preference for the values of preservation of life common in Western countries. ${ }^{196}$

DoDI 2310.08E acknowledges involuntary treatment might occur, stating it should be preceded by "a thorough medical and mental health evaluation of the detainee and counseling concerning the risks of refusing treatment" and that any treatment should be "carried out in a medically appropriate manner."197 These instructions would seem to rule out the use of emergency restraint chairs, but

194 See, e.g., Winkenwerder, Media Roundtable, supra note 192 ("We have a policy that is to preserve life. That policy is an ethical policy. It's in the best interests of the individual who is a hunger striker, for his life to be preserved, in our judgment.").

195 See, e.g., Washington v. Harper, 494 U.S. 210, 227 (1990); Singletary v. Costello, 665 So. 2d 1099 (Fla. Dist. Ct. App. 1996); Thor v. Superior Court, 855 P.2d 375, 385 (Cal. 1993); Comm'r of Corr. v. Myers, 399 N.E. 2 d 452, 458 (Mass. 1979).

196 Allen \& Reyes, supra note 191, at 201.

197 DoDI 2310.08E, supra note 2, at para. 4.7.2. 
nonetheless continue to permit force-feeding of mentally competent prisoners. ${ }^{198}$

However, this legal preference for preservation of life is contrary to professional ethical standards. As previously noted, the Declaration of Tokyo prohibits physicians from using their knowledge to facilitate interrogation and explicitly states, "Where a prisoner refuses nourishment and is considered by the physician as capable of forming an unimpaired and rational judgment concerning the consequences of such a voluntary refusal of nourishment, he or she shall not be fed artificially."199 Further, the WMA's Declaration of Malta, also revised in 2006, perhaps to address activities Guantanamo, states that "[h] unger strikers should not be forcibly given treatment they refuse. Forced feeding contrary to an informed and voluntary refusal is unjustifiable." 200 Thus, forced feeding by MHPs at Guantanamo, while not illegal (and in fact authorized by DoD policy and ordered by military commanders), is directly contrary to ethical standards. ${ }^{201}$

198 See Annas, supra note 191.

199 Revised Declaration of Tokyo, supra note 27, at para. 6.

200 WMA Declaration of Malta on Hunger Strikers, WORLD MED. Ass'N, http://www.wma.net/en/30publications/10policies/h31/ (last visited Dec. 26, 2013).

201 Dr. William Winkenwerder, then Assistant Secretary of Defense for Health Affairs, admitted as much when saying in 2006, "[as for hunger strikes, w]e view what we are doing as largely consistent with that [Malta] declaration." Winkenwerder, Media Roundtable, supra note 192. Indeed, "largely consistent" means that there must be parts that are inconsistent. 


\section{Examples: Sharing Medical Information with Interrogation Teams}

Despite contradictory statements by senior United States officials, it is clear information from detainee medical records was shared with interrogation teams. ${ }^{202}$ In fact, Dr. David Tornberg, then-Deputy Assistant Secretary of Defense for Health Affairs, admitted to-and defendedsharing clinical medical information with interrogators, and he arguing that they "could not conduct their job without that info." 203 The policy of the combatant command with geographic responsibility for Guantanamo explicitly required medical care teams at Guantanamo to share "any information concerning the ... national security mission" to nonmedical personnel. 204

Sometimes this information sharing involved the health provider directly revealing information to interrogators or

202 In one example, "interrogators were told that a detainee's medical files showed he had a severe phobia of the dark and suggested ways in which that could be manipulated to induce him to cooperate." Lewis, Interrogators Cite Doctors'Aid, supra note 110. Other detainees believed what they had told their psychological providers in a patientprovider setting had been shared with interrogators, based on the nature of subsequent interrogations. Hashemian et al., supra note 6 , at 86.

Senior United States officials have made contradictory statements regarding whether, and the extent to which, detainee medical records were shared with interrogators. Slevin \& Stephens, supra note 3, at A1. Brigadier General Rick Baccus, who commanded Guantanamo from March 2002 to October 2002, said new detainees' records were routinely shared with military intelligence personnel and military doctors and medics were available to advise interrogators about the new detainees' health. However, Brigadier General Baccus's successor, Major General Geoffrey Miller, insisted otherwise, denying a claim by the ICRC based on detainee complaints that medical records were being shared with interrogators for the purpose of developing interrogation plans. Id.

203 Bloche \& Marks, Doctors Go To War, supra note 10, at 4. Dr. Tornberg further noted that clinicians made detainees aware there was limited or no doctor-patient confidentiality, a claim that has not been verified. Id.

204 R.A. Huck, Chief of Staff, U.S. Southern Command, Policy Memorandum 8.02 (Aug. 6, 2002), available at http://www1.umn.edu/humanrts/OathBetrayed/Huck\%208-2-02.pdf. 
BSCT members. 205 In other instances, interrogation teams were given access to the medical records, sometimes without the knowledge or assent of the providers and sometimes over their express objection. ${ }^{206}$ This information was used to develop interrogation plans and may have been used to "[c]lear prisoners for harsh interrogation."207

For HPs familiar with extraordinarily limited medical information sharing under United States patient privacy laws, such as the Health Insurance Portability and Accountability Act 208 ("HIPAA"), providing health information to individuals not part of the medical care team would be extraordinarily abnormal. For such providers, sharing information with other HPs-the psychiatrists and psychologists of the BSCTs-rather than interrogators, would likely be easier. However, from a legal and ethical privacy standpoint, these BSCT personnel were no different than laymen-they were not part of the medical treatment team. BSCT personnel routinely reviewed detainees' medical information at Guantanamo, having direct access to detainee medical records through at least June 2004. ${ }^{209}$ Clinical personnel at Guantanamo also made detainee records available to intelligence staff and met with BSCT personnel "to provide information about prisoners' mental health and vulnerabilities."210

205 Lewis, Interrogators Cite Doctors'Aid, supra note 110.

206 As noted above, the New York Times received a specific report from one investigator that a BSCT member reviewed a detainee's file and specifically recommended exploiting the detainee's longing for his mother. Id.

207 MILES, supra note 3, at 55. According to one civilian psychiatrist who visited Guantanamo as part of a monitoring team, detainees' medical records included "names, nationalities, and histories of physical and psychological problems, as well as notes about current complaints and prescriptions" and "psychologists' comments about conditions such as phobias, as well as family details, including the names and ages of a spouse or children." Slevin \& Stephens, supra note 3, at A1. Such information would clearly be valuable to interrogators intending to exploit it for the purpose of causing detainee compliance.

208 Health Insurance Portability and Accounting Act of 1996, Pub.

L. No. 104-191, 110 Stat. 1936 (1996).

209 Army Surgeon General Assessment, supra note 55, at 18-13.

210 Slevin \& Stephens, supra note 3 , at A1. 
Contrary to one commentator's assertion that sharing medical information with interrogators would be a "clearcut violation of the Geneva Conventions," no international law prohibits-clearly or otherwise-sharing personal health information under these circumstances. ${ }^{211}$ Also, contrary to popular assumption, perhaps understandable because of rigorous health privacy laws in the United States like HIPAA, ${ }^{212}$ there is no international or domestic law providing for absolute confidentiality of non-United States citizen detainees' medical records. DoDI $2810.08 \mathrm{E}$ correctly recognizes this legal reality, stating that "[u]nder U.S. and international law and applicable medical practice standards, there is no absolute confidentiality of medical information for any person. Detainees shall not be given cause to have incorrect expectations of privacy or confidentiality regarding their medical records and communications." ${ }^{213}$ In fact, DoDI $2810.08 \mathrm{E}$ specifically authorizes the sharing of patient-specific medical information for "national security-related activity."214

\section{b. Ethics}

In contrast to the relative absence of law constraining the sharing of detainees' personal health information with interrogators, and the DoD regulation specifically authorizing it, ethical standards explicitly limit such sharing. The WMA's Declaration of Tokyo prohibits physicians from using "health information specific to individuals" to facilitate or otherwise aid any interrogation. $^{215}$ Thus, under this rule, even if a physician told a detainee his information would be shared with

211 Id. ("Steven H. Miles, a professor of bioethics at the University of Minnesota, said that using the information in interrogations of detainees would be a 'clear-cut violation' of the Geneva Conventions.").

212 Health Insurance Portability and Accounting Act of 1996, Pub.

L. No. 104-191, 110 Stat. 1936 (1996).

213 DoDI 2310.08E, supra note 2, at para. 4.4.

214 Id.

215 Revised Declaration of Tokyo, supra note 27. 
interrogators, thereby fulfilling his obligation under DoDI $2610.08 \mathrm{E}$ to not mislead the detainees, the subsequent sharing of that information would be prohibited. The American Psychiatric Association also flatly prohibits sharing information: "[p] sychiatrists should not disclose any part of the medical records . . . to persons conducting interrogation of the detainee." By contrast, the AMA's Opinion 2.068(1) provides that physicians must "inform detainees of the extent to which interrogators may have access to the detainee's medical records." Complicating the application of these rules to military physicians and psychiatrists is the fact that they do not have exclusive control of the records. Medical records are the property of the United States, not the individual providers. Thus, while they could fulfill their obligations to not disclose medical records themselves, they would be unable to prevent the United States from disclosing the information to interrogators.

Apart from the usual prohibition on engaging in, tolerating, directing, supporting, advising, or offering training in torture, or cruel, inhuman, or degrading treatment, the APA is silent regarding information sharing. Ostensibly, information sharing in the interrogation context is permissible, except where torture, cruel, inhuman, or degrading treatment, is involved. This is important, because BSCTs are now primarily comprised of psychologists.

Thus, the DoD regulation provides a negative obligation (not to misinform detainees), the AMA imposes an affirmative obligation (to inform detainees of how information will be used), and the WMA and American Psychiatric Association flatly prohibits information sharing. This is an area where professional associations' efforts to curb a particular activity appear to have failed.

\section{Conclusion}

Law does not proscribe MHPs from planning general interrogation, providing interrogation training, planning specific interrogations, consulting with interrogators during 
interrogations, evaluating or monitoring a detainee's health before, during, or after interrogation, providing medical care that incidentally allows interrogation to continue, including forced feeding, or sharing detainee medical information with interrogators. Of the remaining activities that do constitute per se violations of law, such as failure to report abuse, concealing evidence of criminal activity, withholding medical care in exchange for cooperation, and performing nonconsensual experiments, law no more constrains HPs than it does any other service member and the facts do no support allegations that MHPs engaged in such activity.

By significant contrast, nearly all the criticized activities do potentially violate professional ethical standards, including providing general interrogation planning assistance and training, planning specific interrogations, consulting with interrogators during interrogations, evaluating or monitoring a detainee's health before, during, or after interrogation, providing medical care that allows interrogation to continue, sharing detainee medical information with interrogators, failure to report abuse, withholding medical care in exchange for cooperation, participating in forced feeding, and conducting nonconsensual medical experiments.

\section{CONCLUSION: The IMPACT OF THE LAW-ETHICS DIVIDE}

As demonstrated above, there is a significant divide between what the law proscribes and international and domestic professional ethical standards require regarding MHPs' interrogation-related activities. Indeed, "medical ethics as articulated by the WMA are often in conflict with national laws. ..."216 Many legal activities are deemed unethical and health professionals are prohibited from participating.

But so what? Why does it matter that professional ethics stand alone in empowering HPs as guardians of human rights and constraining their HPs' interrogationrelated activities? The negative consequences of the status

216 Allen \& Reyes, supra note 191, at 191. 
quo demonstrate its unacceptability. First, professional ethics alone fail in their effort to empower HPs as guardians of human rights and constrain their HPs' interrogationrelated activities. Second, the law-ethics divide cedes too much policy control over national security issues to nongovernmental professional organizations. Third, based upon the current trajectory, there is a risk that professional ethics will completely eliminate HPs from all aspects of interrogation, which could have disastrous consequences. Finally, the law-ethics divide harms individual HPs.

Though DoD has, for now, implemented regulations addressing some of the professional ethics issues, the law generally constrains HPs no more than it does other service members. MHPs may be proper protectors of human rights in the context of interrogation, but the law does not create or demand that special role. Those hoping HPs might serve as superior protectors against interrogation abuses-or those wishing to criticize HPs' failure to so serve-must rely on professional ethics to accomplish what law has not, a reality demonstrated by the number of vocal efforts to use international and domestic professional associations, state licensing boards, and even state legislatures to accomplish these purposes.

If establishing HPs as special guardians in the context of interrogations is desirable, we must ask whether this reality-where professional ethics specifically empower and constrain HPs' interrogation-related activities while law does not-is prudent or adequate. The potentially deleterious effects on national security and individual providers suggest it is not.

\section{A. The Law-Ethics Gap Leaves MHPs Unempowered to Protect Detainees}

As one commentator has observed, "[j]ust when the nation most needed to draw on these professionals' specialized expertise to limit or counterbalance military excess, a significant number of these professionals failed to 
act in accordance with their professional code of conduct."217 Simply stated, professional ethics alone failed to empower HPs to prevent interrogation-related detainee abuse and, as a consequence, the strategic harm to the United States due to the reputational impact of abuses and the recruiting tool such abuses provided terrorist groups. It is far beyond the scope of this discussion to analyze the national, institutional, cultural, and individual failures that led to the United States abusing detainees it interrogated. However, regarding the facet of that failure discussed in this article, if, as I argue, law did not address most HPs' interrogation-related activities, critics must acknowledge professional ethics alone also failed to constrain such activities.

Admittedly, professional associations' first significant specific responses to alleged interrogation-related abuses in the GWOT came in 2006, over four years after HPs' involvement in interrogation began. Thus, some may argue tightened professional ethics have since succeeded in curbing interrogation abuses. Whether it was professional ethics or the nation's legal response in the form of the DTA that curbed the underlying detainee abuses, professional ethics constrain HPs in a way law does not. Further, commentators continue to argue DoD policy is inconsistent with ethical obligations. Indeed, the continued arrival in these later years of books, articles, and symposia on the subject of HPs' involvement in interrogation-related activities suggests the issue is not resolved. ${ }^{218}$

217 Cassandra Burke Robertson, Organizational Management Of Conflicting Professional Identities, 43 CASE W. RES. J. INT'L L. 603, 604 (2011) (referring to health, legal, and religious professionals).

218 See, e.g., Jonathan Marks \& M. Gregg Bloche, The Ethics of Interrogation-The U.S. Military's Ongoing Use of Psychiatrists, 359 NEW ENG. J. MED. 1090, 1091 (2008) (arguing that though "[DoD] should be credited for requiring behavioral science consultants not to 'perform any duties they believe are illegal, immoral or unethical,' the value of such a mandate is undermined by the confusion [DoD policy] introduces regarding the ethical obligations of health professionals who serve as consultants" and "[DoD's policy] seeks to undermine the positions taken by the AMA and APA concerning physicians' monitoring of interrogations."). Recent articles include Brennan, Torture of Detainees, supra note 3; George J. Annas, American Vertigo: "Dual 
Reminded by Justice Brennan that "[a]fter each perceived security crisis . . . the United States has remorsefully realized the abrogation of civil liberties was unnecessary [but] has proven unable to prevent itself from repeating the error when the next crisis came along," we must look toward the next moment where we hope MHPs will serve as guardians of human rights and ask whether they are sufficiently empowered to do so. ${ }^{219}$ So long as that role is established by professional ethics alone, without the corresponding backing of law, they are not.

While the failure of professional ethics alone to produce the guardians of human rights HPs' promoters envision may be attributed to a variety of causes, two inherent institutional limitations of health professional ethical standards to constrain HPs in the military context.

\section{Military Medical Community is Subordinate to Operational Actors}

First, the medical community is culturally subordinate to the "operational" community in the military. At both the operational "field" level and senior policy level, HPs carry influence, but not final decision-making authority, and many commentators simply overestimate the medical community's ability to influence key decision-makers regarding interrogation techniques. One frequent commentator's assessment summarized this view:

We must educate, mentor and empower [health professionals in the military and intelligence agencies] to be guardians of human rights and to say no to any practice or environment that violates these fundamental

Use," Prison Physicians, Research, and Guantánamo, 43 CASE W. RES. J. INT'L L. 631, 649 (2011); MILES, supra note 3; INTERROGATIONS, Forced Feedings, and the Role of Health Professionals, (Ryan Goodman \& Mindy Jane Roseman eds.) (2009).

219 William J. Brennan, Jr., The Quest to Develop a Jurisprudence of Civil Liberties in Times of Security Crises, 18 ISR. Y.B. HUM. RTS. 11 (1988). Indeed, the future is no place to place our better days. 
norms. If we fail to do this, we will do a great disservice to them, to those they harm (or, at the very least, fail to protect), andultimately-to ourselves. ${ }^{220}$

While HPs should serve as guardians of human rights, anyone who deduces that "education, mentorship, and empowerment" offered by professional ethics alone can establish and empower HPs to become such guardians of human rights and to "just say no" is mistaken.

The idea that education, mentorship, and empowerment can create rank-and-file guardians of rights vastly overestimates the ability of lower-ranking MHPs "in the field" to influence decision-makers. The leader of the BSCT tasked with creating the BSCT Counter-Resistance Strategy Memorandum-that is, the senior health professional advising the interrogators at Guantanamo-was a major (a mid-level commissioned officer), while the commander driving the use of enhanced interrogation techniques was a two-star general, who was himself being pressed for actionable intelligence by four-star generals and cabinetlevel presidential appointees. That health professional's relative power vis-à-vis the commanding general was miniscule, both because of rank discrepancy and because of the cultural role to which medical personnel can be relegated in operational decision-making. ${ }^{221}$ Professional ethics has a minimal impact on operational ("field") commanders' decisions. For good or ill, United States military commanders are more concerned with whether an action is legal or illegal than whether it comports with a particular professional's ethical standards. A commander would likely follow the advice of her legal advisor who

220 Marks, Looking Back, supra note 10, at 47.

221 See Marks, Looking Back, supra note 10, at 30 (noting MHPs are often perceived as "not real soldiers"). This is not a universal problem. Many commanders value the input of their health, legal, and spiritual professional advisors. Unfortunately, as a cultural matter many do not, and merely hoping they will is an unreliable method of ensuring policy influence. Additionally, though the input of MHPs is very important when the health of United States service members is at issue, that is not always the case when the health of others is at issue. 
unequivocally states a particular action is illegal, yet be unlikely to follow the dictates of one of her subordinate's professional ethics. This disparity makes some sense-the commander has a personal stake in not violating the law and has no such interest in following the ethical tenets of a profession of which she is not a part. An individual health professional just "saying no" would at most result in that health professional's removal from the interrogation environment ultimately leading to installation of someone who would say "yes" or to the complete absence of HPs in the interrogation environment. And as discussed below, removal of HPs from the interrogation environment will not prevent abuses from occurring.

Moreover, as the Guantanamo example clearly demonstrates, while policy decisions with national security implications may be influenced by mid-level officers in the field (for example, the BSCT major psychologist and the lieutenant colonel staff judge advocate who respectively created and blessed the enhanced interrogation techniques), they are ultimately made at the highest levels of United States government, sometimes directly contrary to the most experienced and knowledgeable advisors' opinions. ${ }^{222}$ No amount of "education, mentoring, and empowerment" for the major would have put him in a position to alter the Department of Defense's decision to use harsh interrogation techniques.

The gravitational pull of HPs at the senior policy-making levels of the DoD waxes and wanes, resulting in high and low tides of deference to professional ethics. Whether professional medical and psychological ethics have significant influence on policymaking, as may be the case now, or play little role in the formulation of national security strategy, depends on the personalities and agendas

222 For example, the opinions of senior uniformed attorneys regarding acceptable interrogation techniques were disregarded by the Bush Administration. See, e.g., William Fisher, Early Warnings on Prisoner Abuse Ignored, INTER PRESS SERVICE, Aug. 4, 2005 (demonstrating the Judge Advocates General's concerns about harsh interrogation techniques were ignored by Defense Department political appointees), available at http://www.commondreams.org/headlines05/ 0804-07.htm (last visited Dec. 26, 2013). 
of the senior policymakers in a given administration. Even if one accepts that DoD's current policy and regulations affecting HPs' involvement in interrogation demonstrate a respect for the professional ethics of its individual HPs (a position not all accept), such views can be transitory. For example, in 2004, then-Deputy Assistant Secretary of Defense for Health Affairs Dr. David Tornberg suggested medical ethical rules are inapplicable when a physician is assisting interrogators because, in his view, a medical degree is not a "sacramental vow," but rather is a certification of skill, and, therefore, when a doctor participates in interrogation, "he's not functioning as a physician," and the Hippocratic ethic of commitment to patient welfare does not apply. ${ }^{223}$

\section{Professional Dual Loyalty}

Second, the idea that professional ethics can sufficiently establish MHPs as guardians of human rights does not sufficiently account for the problem of professional dual loyalty of MHPs. Whether or not current DoD policy is consistent with professional ethical standards, MHPs may again be forced to choose between their loyalties to the military and their health profession.

The problem of "dual loyalty" is present whenever a professional is obligated by more than one set of professional principles. Whenever HPs-even those not in military service-are involved in activities other than direct treatment of patients, questions of conflicting professional obligations arise. ${ }^{224}$ As Professor Marks and Dr. Bloche have noted:

223 M.G. Bloche \& J.H. Marks, Doctors Go To War, supra note 10, at 4. According to Dr. Tornberg's view, as long as the military maintains a separation of roles between clinical caregivers and physicians with intelligence-gathering responsibilities, assisting interrogators is legitimate. Id.

224 Even outside the military context, HPs may have obligations to others than just their patients, including family members, employers, insurance companies, and governments, all of which may conflict with undivided devotion to the patient. See Leslie London et al., Dual 
Military physicians point to civilian parallels, including forensic psychiatry and occupational health, in arguing that the medical profession sometimes serves purposes at odds with patient welfare. They argue, persuasively in our view, that the Hippocratic ideal of undivided loyalty to patients fails to capture the breadth of the profession's social role. This role encompasses the legitimate needs of the criminal and civil justice systems, employers' concerns about workers' fitness for duty, allocation of limited medical resources, and protection of the public's health. ${ }^{225}$

As demonstrated, MHPs' legal obligation to their military service can conflict with their ethical obligation to their health profession, with each "obligor" stating their obligations trump the others'. ${ }^{226}$

The dual loyalty problem faced by MHPs is demonstrated by calls for primacy from each of the objects of that loyalty. MHPs are simultaneously told they should be a "physician first and a military officer second" 227 and

Loyalty among MHPS: Human Rights and Ethics in Times of Armed Conflict, 15 CAMBRIDGE Q. HEALTHCARE ETHICS 381, 382 (2006).

${ }_{225}$ Bloche \& Marks, Doctors Go To War, supra note 10, at 4.

226 Compare American Psychological Association Amends Ethics Code to Address Potential Conflicts Among Professional Ethics, Legal Authority and Organizational Demands, AM. PsYCHOL. Ass'N (February 24, 2010), http://www.apa.org/news/press/releases/2010/02/ethics-code. aspx (stating members cannot adhere to the law or demands of an organization if doing so would require violating the Code of Ethics) with E.G. Howe, Mixed Agency in Military Medicine: Ethical Roles in Conflict, 1 MIL. MED. ETHICS 331, 335 (2003) (arguing in certain scenarios it is justifiable for military medical providers to elevate the military role above the medical); Carter W. Madden, Physician-Soldier: A Moral Profession, 1 MIL. MED. ETHICs 269, 282 (2003) (arguing in wartime the physician-soldier "is not violating his professional responsibility to relieve pain and suffering; rather it is being met in a special way.")

227 See, e.g., Annas, supra note 191, at 1379 ("Force-feeding at Guantanamo and the Hamdan opinion provide the opportunity for the U.S. military to adopt as formal military doctrine the rule that a 
"[y]ou are first and foremost soldiers, and only after that, doctors." 228 The contrast between ethical standards' relatively tight restrictions and the law's relative silence regarding interrogation-related activities by HPs amplifies the dual loyalty problems already faced by MHPs. As multiple commentators have acknowledged, even those generally critical of military health professional involvement in interrogation, individual HPs cannot resolve the competing obligations by themselves. ${ }^{229}$ Indeed, "we would affirm [military healthcare professionals'] honor, not besmirch it, by acknowledging the tensions between their Hippocratic and national service commitments and by working with them to map a course between the two."230

Not surprisingly, many health ethicists argue that whenever dual loyalty is encountered, loyalty to the health profession should prevail. 231 But this seems an overly simplistic response to a complex problem, especially when national security interests are at stake. While law may never keep pace with changes to ethical standards, where national security interests are at issue, the law should resolve the dual loyalty, rather than leaving it to insufficiently empowered HPs to do so.

This problem of dual loyalty, not unique to HPs in the military, ${ }^{232}$ may be endemic to professionals' military service and not completely remediable, meaning law that resolves the pull of the individual's dual professions is all the more important. Moreover, as important scholarship in identity theory and dual loyalty has articulated, even where

physician in the military is always a physician first and a military officer second.") (emphasis added).

228 See, e.g., Ugur Cilasun, Torture and the Participation of Doctors, 17 J. OF MED. ETHICs S21-22. (Supp. 1991).

229 Rubenstein, supra note 7.

230 Bloche \& Marks, Doctors Go To War, supra note 10, at 6.

231 See, e.g., Annas, American Vertigo, supra note 218, at 649 (arguing that 'the only 'solution' to it is for prison physicians to refuse to comply with any order or request from prison officials, including military commanders in charge of military prisons, that is inconsistent with medical ethics").

232 See, e.g., Robertson, supra note 217, at 613-14 (providing examples of dual loyalty challenges faced by military lawyers and military chaplains). 
the military does not demand a health professional violate or abandon his or her professional ethics, HPs "unconsciously avoid or overlook them."233 Here again, law may be at least a partial answer, as it is more difficult to avoid or overlook law.

While military leaders at all levels would wisely seek to harmonize professional ethics and institutional objectives, and may currently do so, when the next crisis comes, HPs and the nation would be better off with law that resolves dual loyalty issues rather than exacerbates them.

\section{B. The Law-Ethics Gap Cedes Too Much Power to Professional Health Associations}

The status quo of the law-ethics divide cedes too much policy control over national security issues to nongovernmental professional organizations. No argument is necessary that the interrogation of detainees and, by extension, HPs' role therein, has strategic national security implications. With so much at stake, how is it appropriate to bestow upon professional organizations authority to dictate what specific military members may and may not do?

Consider the following hypothetical: a military commander directs a military health professional to assist in a particular task that is vital to national security. The task is irrefutably legal, but constitutes a violation of an international professional association's opinion regarding professional ethics. Is the right answer for the government to throw up its hands and defer to the unelected international professional association? Many health profession ethicists-and perhaps HPs-would likely welcome this development. But is that an appropriate outcome for a democratic nation ostensibly governed by the rule of law?

The value of professional organizations as a conscience for their professions and society at large is irrefutable. Professional associations like the WMA and AMA establish 
extraordinarily helpful worldwide and domestic guidelines that prevent needless suffering. But these organizations are not elected governments nor are they treaty bodies granted authority by sovereign states. Ceding such policy decisions to non-governmental organizations is antithetical to democratic principles.

Some object that "giving legal norms the last word on the limits of professional conduct leaves psychiatrists and psychologists without clear guidance in the face of disagreements between lawyers and policymakers about the application of those norms." 234 Unfortunately, so too does giving malleable ethical standards the last word. Thus, the question is what body should have the "last word" in these matters? International law, domestic law, or ethical standards as articulated by any number of international and domestic professional organizations? While this may seem a tired debate, the conflict between law and ethics in the context of HPs' interrogation-related activities demonstrates the issue is not anachronous.

Of course, the Department of Defense should not have sole authority to dictate what MHPs must or may do. ${ }^{235}$ That is why, when matters with such import to national security are involved, society, through its democratic government, should determine the balance between national security, human rights, and freedoms. If there are specific activities society wants to prevent HPs from engaging in, they should be proscribed by law. Likewise, if we choose to allow HPs to engage in activities, we should empower and protect them by law. While one would hope society would take its cues from the human rightsprotecting professional associations, in a democratic system, the views of unelected and non-representative professional

234 Marks, Doctors as Pawns?, supra note 10, at 724 (noting that "efforts to redefine the scope and meaning of the Geneva Conventions and the prohibition of CID treatment in core human rights treatiesdiscussed above - provide two powerful illustrations of this point.").

235 See, e.g., Marks, Looking Back, supra note 10, at 43 ("When professional organizations issue ethical statements after due deliberation and consultation, and those statements prohibit health professionals from acting in certain ways, the military should respect these statements."). 
associations should not trump, as is arguably the present case with HPs' interrogation-related activities.

\section{The Law-Ethics Gap May Exclude Health Professionals from Interrogation Process}

The current trajectory of more and more restrictive ethical standards pronounced by professional organizations raises the increased possibility HPs could be removed from the interrogation process altogether, either by increasingly restrictive ethical standards or by the choice of MHPs who decide not to subject themselves to the tension between military duty and professional ethics created by the lawethics divide.

Indeed, several commentators have suggested that HPs should, if unable to influence the course of interrogation techniques used, withdraw from the interrogation environment altogether. ${ }^{236}$ Some ethicists take the next step, objecting to HPs' involvement with interrogation altogether, no matter how tame. ${ }^{237}$ Indeed, ethical standards such as the Declaration of Tokyo as revised in 2006, prohibit HPs' participation in interrogation, regardless of its nature. ${ }^{238}$

This position raises numerous policy questions about the benefits and risks of health professional participation that are best decided by an informed representative government, not a domestic or international professions association. For

236 For example, two commentators argued "effective prevention of complicity in torture may simply require the withdrawal of health professionals from the interrogation setting" and that the presence of medical personnel in interrogation settings "does not represent an effective systemic check on the abuse of detainees." See Brewer \& Arrigo, supra note 7 , at 5, 19 (arguing that "effective prevention of complicity in torture may simply require the withdrawal of health professionals from the interrogation setting" and that the presence of medical personnel in interrogation settings "does not represent an effective systemic check on the abuse of detainees").

237 See, e.g., Edmund Howe, Further Considerations Regarding Interrogations and Forced Feeding, in FoRCED FEEDINGS, AND THE ROLE of Health Professionals 85 (Ryan Goodman \& Mindy Jane Roseman eds. 2009).

238 Revised Declaration of Tokyo, supra note 27. 
example, can it really be the case that we would not want a doctor or psychologist to check on a detainee's medical status after questioning? If our only "interrogation method" were calm questioning for four hours at a time, why would it be unethical for a medical professional to do a quick postinterrogation assessment of the detainee to make sure they were okay? Is the only distinction what actually occurs in the interrogation room? If so, how does it make sense to allow medical professionals to evaluate the health of a detainee who has not been interrogated "harshly," while not permitting such an evaluation of detainees who were harshly treated (i.e., those for whom the evaluation is more important)? Is the real distinction about the ethics here what the medical provider's purpose for evaluating the patient? If it is to determine that the detainee is healthy, it is fine; if it is to further the next round of harsh interrogations, it is not? $\mathrm{Or}$ is the real distinction really the underlying activity of the interrogators, over whom the HPs have no control?

A system where HPs are completely uninvolved in providing advice regarding the suitability of interrogation procedures generally or regarding specific activities in light of a particular detainee's health is arguably imprudent for several reasons. First, it suggests the fundamental evil to be prevented is HPs' "complicity in torture," rather than the underlying torture itself. Second, such a policy would effectively require lay people to determine whether certain interrogation activities will result in long-term harm. Some may over-optimistically hope that removal of the HP from the interrogation process would mean the end of the interrogation, but this is most unlikely. Because long-term harm is a legal element of whether something constitutes torture, removing HPs from the process would increase the likelihood of criminal acts being committed by interrogators. More importantly, it would increase the likelihood detainees would be harmed by interrogators ignorant of the medical or mental health consequences of their actions. Further, as allegations discussed in this article demonstrate, assuming we want HPs involved in ensuring detainee health generally (apart from interrogation), it is difficult to exclude such 
professionals completely from "interrogation-related activities."239

The possible withdrawal of HPs from the interrogation environment is not only precipitated by professional associations' direct and increasingly restrictive ethical standards, but also the tension created by the widening lawethics divide between obeying legal military orders and complying with professional ethical obligations. The very real burden this imposes on MHPs, discussed in detail in the next section, may simply cause MHPs to decide to practice medicine and mental health care elsewhere, causing a new difficulty for the military.

\section{The Law-Ethics Divide Harms MHPS}

Contrary to some of the heated rhetoric in the debate over their involvement in interrogation-related activities, MHPs are, as a whole, an extraordinarily selfless group of highly skilled professionals who spend each day satisfying the dual noble goals of serving their country and humanity. It is these HPs who are most acutely aware of the divide between law and ethics because of the professional and personal risks that divide imposes. The impact on individual MHPs of these interrogation-related activities is immense and the professional and personal risks and interests of the individual providers in these ethical and legal questions have been insufficiently examined and protected. Not only are HPs faced with making choices between competing claims for their loyalty, as discussed above, they must make such choices while risking personal

239 Indeed, some critics have gone so far as to blame HPs for abuses simply because the health professional happened to be simultaneously assigned to the detention facility where the abuses occurred. See, e.g., Stephen Soldz et al., An Open Letter to Sharon Brehm, President of the American Psychological Association (June 7, 2007), available at http://www.counterpunch.org/2007/06/07/on-psychologists-and-torture/ (asserting that "James was the commander of the BSCTs at the time the FBI and other law enforcement agents were reporting that severe abuses were occurring at Guantánamo," implying Colonel James was responsible for the abuses). 
consequences created by the divide between law and professional ethics.

\section{Professional Risks}

\section{a. Health Professional Risks}

DoD's position that professional ethics do not apply to HPs not engaged in clinical practice is controversial and further exacerbates the difficulty for MHPs called upon to act in non-clinical roles in a way that contravenes professional ethics. ${ }^{240}$ The potential impacts on a health professional's medical or psychology career need little amplification after reviewing the various ethical pronouncements of the professional associations discussed in this article. While there have thus far been no reported cases of state licensing boards actually disciplining MHPs for their interrogation-related activities, investigations have occurred, and the fear of such action is real for the HPs who have already engaged in interrogation-related activities and for those who might consider doing so in the future. Additionally, the nationally publicized professional disapprobation a health professional could receive from one's professional colleagues-such as that demonstrated by the public identification of individual MHPs involved in interrogations or the open letters written by the APA identifying individual military psychologists-can have real effects on employment and the financial prospects of one's private practice. 241 Thus, while not "binding law," ethical standards can significantly influence HPs' choices, with strong consequences possible for failing to obey ethical standards.

240 See London et al., supra note 224, at 385; Bloche \& Marks, Doctors Go to War, supra note 10, at 3-6.

241 One website identifies lists specific providers alleged to have been involved in interrogation and encourages readers to "sign up to receive e-mail updates when additional health professionals are posted." When Healers Harm, CENTER For CONSTITUTIONAL Rights, http://whenhealersharm.org/category/the-psychologists/ . 


\section{b. Military Professional Risks}

On the other hand, the MHP who chooses to assert professional ethics above "the mission" faces significant military professional risks. In addition to the personal risk of UCMJ action discussed below, there are obvious potential impacts on one's career in the military-like in most large organizations-when one is not considered a "team player." MHPs have a personal career incentive to participate in whatever activities they have been ordered to participate in, regardless of possible ethical objections. ${ }^{242}$

After some military physicians refused to force-feed detainees, the DoD began screening doctors to be assigned to Guantanamo to ensure they would be willing to participate. ${ }^{243}$ While one hopes HPs' good faith claims that such activities would violate their ethics will be respected by the DoD, it is not at all difficult to envision difficulties with this approach. First, one wonders whether MHPs interested in furthering their military careers would be comfortable self-selecting out of an opportunity to deploy in an operational environment. No doubt some would and others would not. A second problem arises if insufficient numbers of HPs agree to participate in a particular questionable activity. Then, DoD will either forego the operational need (unlikely), or require participation by those who are uncomfortable. Some may argue this is a hypothetical concern. Experience has proven otherwise.

Risk to one's military career has personal impacts, too, including financial hardship. Many HPs enter the military in part because of enormous scholarships they receive to attend medical school or other expensive training, and leaving the military early, even if permitted to do so, could

242 See Brewer \& Arrigo, supra note 7, at 15. Though this article's point is well-founded, it cites as an example of how the military superior can exert control over the healthcare professional the outdated situations where military dissenters were compelled to undergo unnecessary and unwanted mental health examinations, a practice effectively banned by the Military Whistleblower Protection Act, 10 U.S.C. $§ 1034$.

243 Susan Okie, Glimpses of Guantanamo-Medical Ethics and the War on Terror, 353 NEW ENG. J. MED. 2529, 2530 (2006). 
mean repaying six-figure sums to the government for failure to complete service obligations.

Some commentators argue that aside from the negative implications on one's military career, there is an inducement to go along with, rather than object to, interrogation activities: "wannabeism." 244 This theory suggests that because some MHPs feel they are treated as inferior members who "aren't real soldiers," the allure of participating in or enabling interrogation is particularly strong, as it provides an opportunity to acquire "socially privileged status . . . and potential acceptance into the innermost sanctum of the intelligence community." 245 While perhaps overstated and not applicable to the majority of MHPs, this is a legitimate concern for some.

\section{Personal Risks}

\section{a. Criminal Liability}

Domestic criminal liability to which United States MHPs might have been subject for interrogation-related activities was largely swept away by the statutory defense created by the DTA. ${ }^{246}$ However, this defense was unavailable prior to enactment of the DTA, meaning for over four years, MHPs (like all others involved in interrogation) were potentially risking criminal prosecution for activities in which they were directed to engage. As noted in Section III, this liability was not just for direct acts of torture, in which HPs

244 Marks, Looking Back, supra note 10, at 30.

245 Id.

246 National Defense Authorization Act for Fiscal Year 2006, Pub. L. No. 109-63, § 1404, 119 Stat. 3136, 3475-76 (2006). The DTA provided a legal defense exists to civil action or criminal prosecution for interrogation-related activities when the United States agent "did not know that the [interrogation] practices were unlawful and a person of ordinary sense and understanding would not know the practices were unlawful." A good faith reliance on the advice of counsel-ostensibly including government counsel such as OLC-is specified to be "an important factor, among others, to consider in assessing whether a person of ordinary sense and understanding would have known the practices to be unlawful." 
were very likely not engaged, but also under various secondary liability theories, including accomplice liability and conspiracy. Perhaps Congress' main motivation in enacting the DTA's statutory defense was to recognize this unfairness.

For service members, potential criminal liability was not just a possibility for participating in interrogation-related activities, but also a possibility for not participating. Under the UCMJ, failure to obey a lawful order is a criminal offense. ${ }^{247}$ Thus, if a military health professional were to refuse to obey an order to participate in an interrogation in some way he believed violated his professional ethics, he could be charged and tried. While the prosecution in such a case would turn on the lawfulness of the order, that is small comfort to someone who would have to endure a criminal prosecution to determine whether his decision to disobey the order was justified. 248 Moreover, as has been demonstrated, it is entirely possible an order could be lawful but unethical for the health professional. This reality is a powerful incentive to disregard professional ethics and a further demonstration of why professional ethical standards alone can be insufficient to constrain the behavior of service members.

Though primarily concerned with criminal prosecution in their own country, United States MHPs, as with other United States personnel, may be justifiably concerned with whether other states will view their activities as "grave breaches" of the Geneva Conventions. Other states may invoke universal jurisdiction to prosecute such war crimes, regardless of the United States' interpretation of the Geneva Conventions. ${ }^{249}$ And as noted in Section III above, accomplice liability may rest on different legal standards in other jurisdictions. Thus, even if HPs are not concerned

24710 U.S.C. $\$ 892$ (2013).

248 When the senior attorneys at DoD and DoJ had opined such activities were lawful, it is easy to imagine an individual service member accused would have difficulty showing otherwise.

249 See Jonathan H. Marks, Mending the Web: Universal Jurisdiction, Humanitarian Intervention and the Abrogation of Immunity by the Security Council, 42 Colum. J. TRANSNAT'L L. 445 (2004). 
about potential prosecution in the United States, they would be ill-advised to ignore that possibility while visiting another country.

\section{b. Civil/Tort Liability?}

Tort liability for participation in interrogation-related activities-at least in the United States-is not a significant concern for MHPs. ${ }^{250}$ While ethical standards can sometimes be invoked to prove negligence or other breaches of standards of care in tort claims (another way in which ethical standards influence HPs), the likelihood of tort claims against MHPs reaching the merits is slim. In addition to government employees' usual defenses to individual civil liability for acts undertaken in one's official capacity under the Westfall Act, ${ }^{251}$ as noted above, the DTA provided a defense available in civil or criminal cases for interrogation-related activities. ${ }^{252}$ Moreover, the MCA made it impossible for anyone to invoke the Geneva Conventions in support of any claim in federal court. ${ }^{253}$

\section{E. Conclusion}

Not all commentators view the divide between ethics and law as problematic. In fact, some argue ethical standards serve the important function of filling a void created by malleable legal standards: "[w]hen legal protections for

250 Indeed, the apparent lack of avenues for civil redress recently prompted a call for some type of financial accountability on the part of involved persons, including HPs. Brennan, Torture of Detainees, supra note 3 .

251 The Westfall Act, 28 U.S.C. $§ 2679$, was passed in 1988 as an amendment to the Federal Torts Claim Act to protect federal employees from personal liability for common law torts committed within the scope of their employment, allowing the United States to be substituted as a defendant in such suits.

252 National Defense Authorization Act for Fiscal Year 2006, Pub. L. No. 109-63, § 1404(a), 3475-76 (2006). This likely extinguished any possibility of claims under the Torture Victim Protection Act ("TVPA"), 28 U.S.C. $§ 1350$, or the Alien Tort Statute, 28 U.S.C. $\$ 1350$.

253 Military Commissions Act of 2006, Pub. L. No. 109-366, §5, 120 Stat. 2600 (2006). 
detainees are being undermined, it is all the more important that professional ethics (in particular, medical ethics) speak clearly and that codes of ethics do not become subordinate to, or dependent upon, unilateral reinterpretations of legal doctrine." 254 While a valid aspiration, unfortunately, professional ethical standards have proven to be as malleable as legal doctrine, as demonstrated by the American Psychological Association's multiple contrary pronouncements within a few years or the fact that a host of activities that were previously not "unethical" suddenly became so in 2006, once the WMA, AMA, and American Psychiatric Association altered their interrogation-related ethical standards to prohibit more than just direct torture. The appropriate response to the law-ethics divide seems not only to have professional ethics fill the cracks in the law, but for the cracks in the law to be narrowed.

Professional ethics are neither irrelevant nor unimportant; they play an essential role. Additionally, we are reminded that "ethical codes should do more than reflect fundamental legal prohibitions." 255 While true, this suggestion is hortatory if HPs are required to make unsupported choices when facing competing obligations. Strong ethical standards can have the effect of changing attitudes and behavior. However, in the case of interrogation, if the goal is to elevate MHPs as superior guardians of human rights, professional ethics have proven insufficient.

But law is no panacea. History has demonstrated unclear law can be as malleable as ethical standards (e.g., the Torture Memos). ${ }^{256}$ However, this is not a persuasive

254 Marks, Doctors as Pawns, supra note 10, at 713.

255 See, e.g., id.

256 Indeed, some argue the legal implications of HPs' activities relating to torture are not an important aspect of curbing torture because the legal restraints have been so malleable. Marks, Looking Back, supra note 10, at 27 (arguing that the Bush administration engaged in a "campaign of legal exceptionalism that sought to dispense with or render nugatory domestic and international legal norms that should have protected detainees from abuse," which increased the likelihood detainee abuse would occur). 
argument against law per se, but rather against law that fails to clearly and sufficiently proscribe and prescribe behavior. Indeed, as demonstrated in this article, evidence is slim that HPs engaged in activities where law clearly proscribed behavior, such as with medical experiments, withholding care to obtain cooperation, and concealing evidence of abuse. This at least suggests clear law can work.

Perhaps the most troubling aspect of the invocation of the law by critics of MHPs' interrogation-related activities is that it perpetuates the myth that the law actually addressed, and arguably thus constrained (or should have), HPs' behavior or supported HPs as protectors of detainee rights. This mistake allows reformers in search of solutions to point to law as a failure and cast it aside prematurely, arguing "[i]llegality has not been decisive in the past to deter some advocates of aggressive techniques." 257

Rather than argue HPs violated law or conflate law and ethics, those who wish to establish HPs as guardians of human rights and defenders against torture and cruel, inhuman, and degrading treatment should argue the opposite. They should embrace the idea that international and domestic law has been insufficient to the task and that reliance on professional ethical norms alone is insufficient. Only when persuasively demonstrated that current law is insufficient might the law change to more clearly support HPs as guardians of human rights. In the meantime, professional ethics serve as a too-flexible and too-political tool for HPs defending human rights in the interrogation context, both because their acceptance by decision makers is unpredictable and because they give too much authority to non-governmental actors.

Law leaves unresolved the question of whether MHPs should engage in the types of interrogation-related activities frequently criticized, thus imperiling national security and individual HPs. Whether or not current law sufficiently proscribes the underlying conduct of torture, cruel, inhuman, or degrading treatment, experience in the GWOT 
suggests professional ethical standards standing alone, without the corresponding support of law, are insufficient to establish HPs as special guardians of human rights. The discussion of whether such professionals should serve in that capacity, and, if so, how that role should be recognized and supported, should not assume or imply the law already answers those questions. It does not. 